\title{
Is schizoaffective disorder a distinct categorical diagnosis? A critical review of the literature
}

\author{
Daniel J Abrams' \\ Donald C Rojas' \\ David B Arciniegas ${ }^{1,2}$ \\ 'Department of Psychiatry; \\ ${ }^{2}$ Neurobehavioral Disorders Program, \\ Departments of Psychiatry \\ and Neurology, University \\ of Colorado School of Medicine, \\ Denver, CO, USA
}

\begin{abstract}
Considerable debate surrounds the inclusion of schizoaffective disorder in psychiatric nosology. Schizoaffective disorder may be a variant of schizophrenia in which mood symptoms are unusually prominent but not unusual in type. This condition may instead reflect a severe form of either major depressive or bipolar disorder in which episode-related psychotic symptoms fail to remit completely between mood episodes. Alternatively, schizoaffective disorder may reflect the co-occurrence of two relatively common psychiatric illnesses, schizophrenia and a mood disorder (major depressive or bipolar disorder). Each of these formulations of schizoaffective disorder presents nosological challenges because the signs and symptoms of this condition cross conventional categorical diagnostic boundaries between psychotic disorders and mood disorders. The study, evaluation, and treatment of persons presently diagnosed with schizoaffective may be more usefully informed by a dimensional approach. It is in this context that this article reviews and contrasts the categorical and dimensional approaches to its description, neurobiology, and treatment. Based on this review, an argument for the study and treatment of this condition using a dimensional approach is offered.
\end{abstract}

Keywords: schizoaffective disorder, schizophrenia, bipolar disorder, manic-depressive disorder

\section{Introduction}

Schizoaffective disorder is characterized by persistent psychosis (eg, hallucinations, delusions) and mood episodes of depressive, manic, and/or mixed types. Although the DSM-based classification of psychiatric disorders identifies schizoaffective disorder as a specific clinical diagnosis, there remains a lack of consensus regarding both the conceptual and clinical aspects of this condition. It is possible that schizoaffective disorder simply reflects the co-occurrence of two relatively common psychiatric illnesses, schizophrenia and a mood disorder (major depressive disorder or bipolar disorder), and therefore merits no unique identification in psychiatric nosology. Alternatively, schizoaffective disorder may be a variant of schizophrenia in which mood symptoms (ie, sadness, euphoria, irritability) are more prominent and severe than usual but not inherently unusual in type. Conversely, this condition may reflect severe forms of major depressive or bipolar disorders in which episode-related psychotic symptoms fail to remit completely between mood episodes (Marneros et al 1990, 1991; Dell'Osso et al 1993).

Such debates reflect a categorical approach to the classification of mental illness: in other words, an approach that requires the organization of clinical conditions into distinct categories (ie, Axis I vs Axis II, psychotic disorder vs mood disorder, schizophrenia vs schizoaffective disorder vs bipolar disorder, etc.). Although research efforts based on this approach require categorical distinctions between conditions under study, common clinical experience suggests that the psychiatric conditions with which many patients present do not conform completely, and sometimes not at all, to categorical diagnoses. 
An alternate approach to the study and treatment of psychiatric disturbances is to view psychiatric symptoms as disturbances within dimensions of neurobehavioral function. Perceptual processing and interpretation (ie, hallucinations and delusions) are dimensions of neurobehavioral function in which impairments are expressed to greater or lesser degrees among persons with a variety of neuropsychiatric conditions (Liddle et al 2006; Maier 2006). A dimensional approach to psychiatric diagnosis regards schizophrenia in its canonical form as a condition at the severely disordered end of the perception and information interpretation continuum and at the normal end of the emotional regulation continuum, bipolar disorder as the converse of schizophrenia in these regards, and schizoaffective disorder as a condition reflecting severe disturbances in all of these dimensions of neurobehavioral function.

Both categorical and dimensional approaches to the study and treatment of schizoaffective disorder are represented in the psychiatric literature, making difficult the development of a clear clinical and neurobiological framework within which to consider this condition. In this article, we review clinical and neurobiological studies of schizoaffective disorder for the purpose of determining whether a categorical approach to psychiatric diagnosis provides a useful heuristic for the study and treatment of this condition. Evidence both supporting and challenging this approach is considered. Sources of data for this review were derived from a PubMed-based literature search, the criteria for which included first all articles with the MeSH heading of schizoaffective disorder and then containing keywords relevant to the sections into which this article is organized: epidemiology, including incidence and prevalence, age of onset, gender, clinical presentation, and natural history; neurobiology, including neuropsychological findings, neuroimaging, electrophysiology, neuroendocrine, neurochemical, and genetic features; and treatment. The section on treatment was limited to randomized controlled clinical trials (RCTs), metanalyses of clinical trials, and review articles in which schizoaffective disorder was a focus of treatment or in which persons with schizoaffective disorder represented a nontrivial number of study subjects. Where previously published reviews in reference textbooks or in the DSM-IV-TR sufficed for the purposes of brevity, these sources were used and are cited.

Based on this review, we argue that a dimensional approach to the study and treatment of persons with persistent psychosis and episodic mood disturbances (ie, schizoaffective disorder in categorical diagnostic parlance) affords a more useful framework within which to study and treat persons with this condition. We argue further that neurogenetic studies will be particularly informative when a dimensional approach to the study and treatment of schizoaffective disorder is applied.

\section{Historical considerations}

The term "schizoaffective psychosis" was coined by Jacob Kasanin in 1933 (Kasanin 1994), who recognized in some patients the co-occurrence of symptoms suggesting both schizophrenia and mood (or, in the nosology of his era, "affective") disorders. Kasanin described persons with this condition as experiencing relatively good pre-illness psychosocial adjustment, an abrupt emotional presentation, less social withdrawal or passivity, a shorter course of illness, and relatively good recovery when compared to persons with schizophrenia. Consistent with this formulation, the first (1952) and second (1968) editions of the Diagnostic and Statistical Manual of Mental Disorders (DSM) regarded schizoaffective disorder as a subtype of schizophrenia (see review in Wilson 1993). Although the fundamental concept of schizoaffective disorder as a psychotic disorder was maintained in DSM-III, this condition was separated from schizophrenia and instead assigned to the category "psychotic disorder not otherwise classified." Importantly, none of these classification systems offered criteria specifically for schizoaffective disorder. During this time, some reports also began describing this condition as more similar to the mood disorders than to schizophrenia (Adler and Strakowski 2003; Strakowski et al 2003). Not surprisingly, more than 24 (ostensibly) different definitions of schizoaffective disorder were developed in the years that followed (Winokur et al 1996).

The research diagnostic criteria (RDC) (Spitzer et al 1978) made one of the first attempts to distinguish schizoaffective disorder from psychotic mood disorders; these criteria required not only the co-occurrence of psychotic and mood symptoms but also the persistence of psychotic symptoms for at least 1 week in the absence of prominent mood symptoms. Two diagnostic sub-groups were described on the basis of the quality of the most prominent types of mood symptoms: schizoaffective mania or schizoaffective depression. This left clinicians with the sometimes daunting task of deciding whether mood symptoms had resolved sufficiently to merit a diagnosis of schizoaffective disorder or instead whether their persistence, even if in partial form, instead merited a diagnosis of an incompletely resolved psychotic mood disorder. This approach to the diagnosis of schizoaffective disorder permitted a liberal assignment of schizoaffective 
disorder where it met the research needs of investigators, and complicated the literature regarding this condition more than would application of stricter diagnostic criteria (Berner and Simhandl 1983).

An attempt to address this problem was made in the DSM-III-R (1987) (APA et al 1987), in which the diagnosis of schizoaffective disorder required the persistence of psychotic symptoms for at least two weeks beyond the resolution of mood symptoms. Marneros and colleagues (1989a) further suggested that a diagnosis of schizoaffective disorder be assigned only when the mood symptoms are overtly melancholic or manic. The intent of that suggestion appears to have been to dissuade clinicians from assigning a schizoaffective disorder diagnosis rather than schizophrenia solely on the basis of prominent but relatively minor depressive symptoms or euphoria. Beyond these refinements, however, the diagnostic criteria for schizoaffective disorder offered in subsequent editions of the DSM remain largely unchanged (Frances et al 1995).

\section{Phenomenonology of schizoaffective disorder}

As noted in the preceding section, the DSM-IV-TR applies a categorical approach to the diagnosis of schizoaffective disorder, and then defines this condition according two the two major dimensions of neurobehavioral function it affects: thought (information processing) and mood (emotional regulation). The disturbance of thought must include two (or more) of the 'A' schizophrenia symptoms for a significant portion of time during a 1-month period (or less if successfully treated). The A symptoms include delusions, hallucinations, disorganized speech and grossly disorganized or catatonic behavior. The mood disorder may include episodes that meet diagnostic criteria for a major depressive episode (which must include depressed mood), manic episode, or mixed episode. The symptoms that meet criteria for a mood episode are present for a substantial portion of the total duration of the active and residual periods of the illness. As noted above, schizoaffective disorder is further divided into two subtypes based on the type of mood episodes with which the patient presents: bipolar or depressed. As an additional criterion, the DSM-IV states that during the period of illness there must be delusions or hallucinations for at least 2 weeks in the absence of prominent mood symptoms. Lastly, the symptoms meeting criteria for schizoaffective disorder may not be due to the direct physiological effects of a substance (eg, a drug of abuse, a medication) or a general medical condition.
In light of the substantial heterogeneity in the types of information processing and emotional regulation disturbances observed among persons with schizoaffective disorder, its status as a specific diagnostic category is dubious, at best. We suggest that it is simpler, and probably less confusing, to note first that some patients experience clinically substantial disturbances in both of these domains of neurobehavioral function and to describe thereafter those disturbances carefully. This dimensional approach would avoid the categorization of patients into mood disorders with psychotic features, schizophrenic disorders with minor mood disturbances, and schizoaffective disorder based on symptoms that are present at some point and to some degree in all of these conditions.

However, some authors have argued that subtle differences in clinical symptoms may distinguish between persons with schizoaffective disorder, schizophrenia, and bipolar disorder. For example, it has been reported that delusions at first presentation are more frequent among persons with schizophrenia and schizoaffective disorder than among persons with bipolar disorder, whereas hallucinations are more common among persons with schizophrenia than among those with schizoaffective or bipolar disorders (Whaley 2002). Shenton and colleagues (1987) report that manic schizoaffective disorder patient tend to lack the humor and playfulness of manic bipolar patients, and are similar to schizophrenic patients in terms of idiosyncratic verbalizations, autistic thinking and confusion (Shenton et al 1987). By contrast, Pini and colleagues (2004) observed no differences in the frequency of specific types of delusions and hallucinations between subjects with schizophrenia, schizoaffective disorder, psychotic mania and psychotic mixed mania, and argued that in clinical practice such subtle distinctions in clinical symptoms rarely clarify diagnosis along categorical boundaries (Pini et al 2004). Again, the lack of clear and consistent phenomenological distinctions between these conditions argues against the usefulness of a categorical diagnostic approach to schizoaffective disorder.

In fact, persons with schizoaffective disorder (as well as schizophrenia and psychotic mood disorders) often experience dysfunction in other neurobehavioral domains of function. In a psychiatric nosology that relies on categorical distinctions, dysfunction in other neurobehavioral domains may require the assignment of additional clinical diagnoses. For example, Byerly and colleagues $(2004,2005)$ observed that of 100 men with a diagnosis of schizophrenia or schizoaffective disorder, $30 \%$ have obsessive-compulsive symptoms. Strauss and colleagues (2006) found that in 165 male patients with schizophrenia or schizoaffective disorder nearly 
$50 \%$ experienced symptoms consistent with a diagnosis of posttraumatic stress disorder (PTSD), and that the presence of such symptoms was associated with a higher risk of suicidality. These observations are useful in that they identify other neurobehavioral dimensions (eg, stereotypies or ritualistic behaviors in the case of obsessive-compulsive disorder and anxiety and/or trauma-related symptoms in the case of PTSD) that also may be affected by the neurobiological process producing the phenomenology schizoaffective disorder. However, when the presence of such symptoms entails the assignment of additional diagnoses, as is the case in a categorical diagnostic nosology, it violates the rule of parsimony: if obsessive-compulsive symptomatology is present in nearly a third of persons with schizoaffective disorder and posttraumatic stress disorder symptoms are present in nearly half of persons with schizophrenia and schizoaffective disorder, the utility of identifying such symptoms by diagnoses separate from the primary clinical condition with which the patient presents (ie, schizoaffective disorder) is questionable. Alternatively, and perhaps more usefully, such observations may suggest the propensity of the underlying neurobiology to be expressed across multiple dimensions of neurobehavioral function.

\section{Natural history of schizoaffective disorder}

Differences in the natural history of schizophrenia, bipolar disorder, and schizoaffective disorder are among the features often purported to facilitate distinctions between these conditions. However, the lack of diagnostic reliability and stability - particularly in the case of schizoaffective disorder - presents a serious challenge to such arguments. For example, Maj and colleagues (2000) independently interviewed 150 patients using two psychiatrist diagnosticians and reviewed reliability for individual elements of the DSM-IV criteria for schizoaffective and mood disorder diagnosis. They report lower inter-rater reliability scores for schizoaffective disorder when compared with those for manic and depressive diagnoses. Vollmer-Larsen and colleagues (2006) re-evaluated hospital records and discharge summaries of 59 patients with hospital discharge diagnoses of schizoaffective disorder and found that using an operational criteria checklist, none of the patients fulfilled lifetime diagnostic criteria for schizoaffective disorder and only six patients met possible ICD-10 criteria for schizoaffective disorder. They argued for a moratorium on the use of schizoaffective disorder as a psychiatric diagnosis on the basis of its poor stability over time.
Similarly, Schwartz and colleagues (2000) report relatively high stability of diagnosis at re-evaluation 6- and 24-months later among persons with schizophrenia (92\%), bipolar disorder (83\%), and major depression (74\%), and relatively poor stability of diagnosis among persons with psychosis not otherwise specified (44\%), schizoaffective disorder (36\%), and brief psychotic disorder (27\%). In cases where diagnostic reassignment at 24-months was required, the most frequent shift was to a schizophrenia-spectrum disorder. A similar point is made by Whaley (2002) in a retrospective case review investigating the presenting features schizoaffective disorder at initial evaluation and the effect of those features on diagnosis. They observed that patients whose index episode is depressive are more likely to receive a bipolar diagnosis whereas those whose index episode is manic are more likely to receive a diagnosis of schizoaffective or a bipolar disorder. In other words, the clinical features of the presenting episode influence assignment of diagnosis despite the absence of the longitudinal data required to make substantiate such diagnoses.

The relative lack of stability and reliability of diagnosis influence other elements of schizoaffective disorder, including ascertainment of outcome and prognosis. Some studies suggest that the symptomatic and long-term function of persons with schizoaffective disorder is similar to that associated with schizophrenia (Tsuang and Coryell 1993; Harrow et al 2000; Benabarre et al 2001). Other studies suggest a better symptomatic and functional outcome of schizoaffective disorder when compared to schizophrenia and an outcome similar to that of mood disorders (Marneros et al 1989b; Tohen et al 2000). Still others suggest that the outcome of persons with schizoaffective disorder is better than that of those with schizophrenia but worse than those with mood disorders (Benabarre et al 2001; del Rio Vega and AyusoGutierrez 1990, 1992).

These often contradictory observations leave entirely uncertain the natural history of schizoaffective disorder. Given that schizoaffective disorder reflects the occurrence of variable degrees of dysfunction along dimensions of neurobehavioral function prominently disturbed in schizophrenia and also in mood disorders, it is not surprising that such contradictions in ascertainment of outcome are observed. Variations in the dimensions of neurobehavioral function emphasized in the assignment of a schizoaffective disorder diagnosis (ie, information processing, emotional regulation, or both) would predictably vary in the manner in which they compare to patients whose illness reflect relatively "pure" disturbances in only one of these dimensions. As suggested 
by Vollmer-Larsen and colleagues (2006), a categorical diagnosis of schizoaffective disorder will produce problems in the study of outcomes among persons assigned this diagnosis. By contrast, a dimensional approach - one that emphasizes the type and severity of disturbances in specific domains of neurobehavioral function - may permit a more useful tracking of outcome, particularly as regard to the effects of dysfunction in information processing and emotional regulation on the ability of patients to meet the challenges of everyday life.

\section{Epidemiology Incidence and prevalence}

Although the DSM-IV-TR states without citation that the prevalence of schizoaffective disorder is less than of schizophrenia, there are at present few data on which to base firm estimates of the prevalence of schizoaffective disorder. Scully (2004) and Marneros (2003) offer data suggesting that the lifetime prevalence of schizoaffective disorder ranges between 0.2\%-1.1\% (Zarate et al 1997; Marneros 2003; Scully et al 2004) report a higher frequency ( $9 \%$ ) of schizoaffective disorder among hospitalized psychiatric inpatients. In a more recent Spanish study of 138 outpatients, nearly identical rates of schizoaffective disorder and schizophrenia are reported; each of which was slightly half as common as bipolar disorder (type I) (Benabarre et al 2001).

Schizoaffective disorder appears to be rare among psychotic children (Werry et al 1991). The diagnosis of schizoaffective disorder among younger persons may be more challenging than among adults. Relative difficulty arriving at this diagnosis may be a function of greater uncertainty compared with adults regarding symptoms and diagnostic stability over time (McClellan and McCurry 1999; Hollis 2000). In addition, co-morbidity of intellectual disabilities (Friedlander and Donnelly 2004) and potential issues with substances of abuse and/or medications in this age range (Malla et al 2000) may complicate the diagnosis and consequently identify the incidence and prevalence.

The limited literature on prevalence and incidence suggests that schizoaffective disorder, at its most frequent, is as prevalent as schizophrenia and less common than bipolar disorder. When diagnostic stability is entered into estimates regarding the prevalence of schizoaffective disorder, it appears that schizoaffective disorder is less common than bipolar disorder or schizophrenia. As noted in the preceding sections of this article, the wide range of estimates of prevalence of schizoaffective disorder should prompt concerns regarding the methods by which this diagnosis is ascertained. In studies emphasizing disturbances along the information processing dimension, the estimated prevalence of schizoaffective disorder would be expected to be similar to that of schizophrenia but less than that of bipolar disorder. Conversely, if severe disturbances along both information processing and emotional regulation are emphasized in categorical diagnosis, then schizoaffective disorder would be expected to be less common than both schizophrenia and bipolar disorder. Co-morbidity of schizophrenia and bipolar disorder appears to yield estimates of the prevalence of schizoaffective disorder reported to date: if co-morbidity explained the diagnosis of schizoaffective disorder, then its prevalence should be the product of that for schizophrenia multiplied by that of bipolar disorder with psychosis and/or psychotic depression (ie, a very low prevalence, and one much lower than that of any of these conditions alone). Given the variability in the extent to which disturbances in these dimensions of neurobehavioral function are considered relevant to categorical diagnosis, similar variability is prevalence estimates seems unavoidable. If, however, a dimensional approach to the evaluation and treatment of persons with neurobehavioral disturbances is used then such variability becomes less relevant; the focus of concern would then become identifying the frequency with which such disturbances occur regardless of "diagnosis" and whether such disturbances are functionally relevant.

\section{Age of onset}

Schizoaffective disorder appears to have a broad age of onset in adults (del Rio Vega and Ayuso-Gutierrez 1990). Marneros and colleagues (1990) prospectively interviewed and reviewed records of approximately 900 people with either schizophrenia, mood disorders, or schizoaffective disorder (Marneros et al 1990). Approximately one third of patients with schizoaffective disorder developed the condition between ages 25 and 35, one third developed the condition prior to age 25 (similar to the mean age of onset for schizophrenia in this study) and one third developed the condition after age 35 (simarly to the mean age of onset for bipolar disorder in this study). Angst and Preisig (1995) observed earlier ages of onset among adults with schizoaffective disorder unipolar and bipolar subtypes than among adults with "pure" unipolar and bipolar mood disorders (Angst and Preisig 1995). Similarly, Dell'Osso and colleagues (1993) observed a younger age of onset among adult subjects with schizoaffective disorder than among subjects whose illness was characterized by either psychotic mania or psychotic mixed mood episodes (Dell'Osso et al 1993). Although pediatric onset of schizoaffective disorder is uncommon, the 
age at which this illness first occurs does not appear to differ from that of either pediatric-onset schizophrenia or bipolar disorder (approximately 14 years) (Werry et al 1991).

The available evidence suggests that the age of onset range for adult schizoaffective disorder spans the age of onset of bipolar disorder and schizophrenia and the median age is between the median age of schizophrenia and bipolar disorder. Such variability would be expected if schizoaffective disorder if is understood as variant of either bipolar disorder or schizophrenia, a co-occurrence of these two conditions, or instead a distinct clinical condition. If schizoaffective disorder represents a co-occurrence of two distinct diagnoses (schizophrenia and a mood disorder), then the age of onset of schizoaffective disorder should be identical to schizophrenia: the first-onset of symptoms meeting diagnostic criteria for schizophrenia should not differ between these conditions. If instead age of onset is a variant of bipolar disorder in which there is persistence of psychotic symptoms between mood episodes, then age of onset of schizoaffective disorder should be similar to that of the mood disorder of which it is a variant (ie, bipolar or major depressive disorder).

That both of these scenarios explain age of onset in approximately one-third of cases each and fails to explain age of onset in the remaining third of cases suggests, at a minimum, that these methods of establishing the onset of schizoaffective disorder is problematic. By contrast, if categorical diagnoses are abandoned in favor of a dimensional approach to identifying functionally significant disturbances in information processing and mood, then the need to even make comparisons between ages of onset across diagnostic categories is unnecessary. Instead, it would suffice as a starting point in clinical practice to note that the onset of clinically important disturbances in information processing tends to antedate the onset of functionally significant disturbances in emotional regulation. Regardless of the domain in which neurobehavioral disturbances arise initially, however, vigilance for disturbances in the other is maintained and measures designed to prevent and/or treat disturbances in both domains are undertaken.

\section{Gender}

The DSM-IV-TR states without reference that schizoaffective disorder probably occurs more often in women. This is consistent with Marneros and colleagues (1990b) report that two-thirds of persons with schizoaffective disorder are female, an observation echoed by other studies (Angst et al 1980; Marneros et al 1990; Lenz et al 1991). If clinically significant disturbances in emotional regulation are more common among women, then it should not be surprising that schizoaffective disorder occurs more frequently in women (Cohen 2003). As in previous sections, it might be more useful if clinicians remained vigilant for clinically significant disturbances in emotional regulation among women with information processing deficits (ie, psychotic symptoms) in the service of proactively preventing or treating such problems rather than focusing instead on categorical diagnostic reassignment.

\section{Neurobiology of schizoaffective disorder}

It is reasonably well accepted that the clinical phenomena used to characterize schizophrenia, mood disorders, and schizoaffective disorder are manifestations of disturbances in multiple domains of neurobiological function. These disturbances are amenable to study using neuropsychological, neuroimaging, electrophysiologic, neurochemical, and genetic investigations. Studies investigating the neurobiology of schizoaffective disorder separate from that of schizophrenia or mood (usually bipolar) disorders are few; instead, most include subjects with schizoaffective disorder among those with either schizophrenia or bipolar disorder. At first glance, the tendency to include persons with schizoaffective disorder in one of these two groups would appear to bespeak some measure of agreement among researchers regarding the difficulty of clearly distinguishing between persons with schizoaffective disorder and these other conditions on the basis of their neurobiological features. While this remains a possibility, it is also noteworthy that most investigations focus on only one or a few neurobiological disturbances that reflect a specific domain of neurobehavioral function, usually either information processing (manifesting as psychosis or related cognitive impairments) or emotional regulation but not both. In effect, studies investigating the neurobiology of schizoaffective disorder use a dimensional approach to study-group assignment.

With this in mind, the following sections review the neurobiology of schizoaffective disorder as revealed by the inclusion of persons in study groups with dysfunction in information processing, emotional regulation, or both. It will become clear that when information processing, by any method, is the focus of study then persons with schizoaffective disorder are neurobiologically indistinguishable from those developing similar information processing deficits in any psychiatric diagnostic context (ie, schizophrenia or psychotic mood, and particularly bipolar, disorders). By contrast, when emotional regulation is the focus of study then persons with schizoaffective disorder are indistinguishable neurobiologically from those with mood disorders. Implications of these findings on future investigations 
regarding the characterization and treatment of persons with schizoaffective disorder will be summarized after presenting the data supporting this argument.

\section{Neuropsychological testing}

Much like schizophrenia, schizoaffective disorder is associated with impairments in frontally-mediated cognition, including working memory, alternating attention, information recall, category generation, abstraction, and motor planning (Table 1; Kolakowska et al 1985; Oltmanns et al 1985;
Mitrushina et al 1996; Bryson et al 1997; Manschreck et al 1997; Bryson et al 2002; Gooding and Tallent 2002; Brenner et al 2003; Woodward et al 2004; Goldstein et al 2005; Stip et al 2005; Glahn et al 2006; Nangle et al 2006; Pope and Kern 2006; Roofeh et al 2006). In only two studies was it noted that schizoaffective disorder was associated with better neuropsychological performance on such tests than persons with schizophrenia (Goldstein et al 2005; Stip et al 2005). However, in this first of these studies, the differences were few and suggested only that

Table I Neuropsychological studies of persons with schizoaffective disorder

\begin{tabular}{|c|c|c|c|}
\hline Reference & Population & Measures & Findings \\
\hline Bryson et al 1997 & $\begin{array}{l}S C Z=55 \\
S A D=8\end{array}$ & $\begin{array}{l}\text { WCST,WAIS-R, Hopkins Verbal } \\
\text { Learning, Gorham's Proverbs, CPT }\end{array}$ & $\begin{array}{l}\text { Greater severity of mood symptoms was } \\
\text { associated with perseverative errors, fewer } \\
\text { complete categories on WCST and a } \\
\text { greater number of errors on CPT. }\end{array}$ \\
\hline Woodward et al 2004 & $\begin{array}{l}S C Z=62 \\
S A D=6\end{array}$ & RAVLT, BVMT, SSPI & $\begin{array}{l}\text { In a combined group of SAD and SCZ } \\
\text { patients, an association was found between } \\
\text { psychomotor poverty and deficit of episodic } \\
\text { memory. }\end{array}$ \\
\hline Glahn et al 2006 & $\begin{array}{l}S C Z=15 \\
S A D=15 \\
B M D=26 \\
\text { Controls }=32\end{array}$ & WAIS, DRT & $\begin{array}{l}\text { Patients with BMD, SCZ and SAD had } \\
\text { deficits on backward digit span. Patients } \\
\text { with a lifetime history of psychosis had } \\
\text { impairment in spatial delayed response task. }\end{array}$ \\
\hline Gooding et al 2002 & $\begin{array}{l}S C Z=24 \\
S A D=12 \\
\text { Controls }=29\end{array}$ & Nonverbal working memory & $\begin{array}{l}\text { SCZ and SAD patients performed poorly } \\
\text { on working memory tasks that are based on } \\
\text { the identity and/or features of the stimulus } \\
\text { (ie, object-based working memory tasks) as } \\
\text { well as on a working memory task based on } \\
\text { the spatial location of the stimulus. }\end{array}$ \\
\hline Gooding et al 2002 & $\begin{array}{l}S C Z=34 \\
S A D=23 \\
\text { Controls }=30\end{array}$ & Spatial working memory and WCST & $\begin{array}{l}\text { Both SAD and SCZ had deficits which } \\
\text { differed from controls but not each other. }\end{array}$ \\
\hline Nangle et al 2006 & $S C Z=50 S A D=18$ & WAIS, CPT, WTAR, WMS & $\begin{array}{l}\text { I/3 of patients were classified as suicide } \\
\text { attempters and } 2 / 3 \text { as nonattempters in an } \\
\text { Irish Population. SCZ and SAD patients who } \\
\text { are attempters outperformed nonattempters } \\
\text { in attention and verbal fluency. }\end{array}$ \\
\hline Goldstein et al 2005 & $\begin{array}{l}S C Z=63 \\
S A D=20 \\
\text { Controls }=21\end{array}$ & WAIS and Trails & $\begin{array}{l}\text { Cognitive function of SAD and paranoid } \\
\text { subset of SCZ subjects were more } \\
\text { cognitively intact than subjects with } \\
\text { undifferentiated and residual types of SCZ. }\end{array}$ \\
\hline Manschreck et al 1997 & $\begin{array}{l}S C Z=19 \\
S A D=19 \\
M D D=19 \\
\text { Controls }=19\end{array}$ & Verbal recall with alteration of context & $\begin{array}{l}\text { SCZ subjects attain smaller gains in recall } \\
\text { when context is increased compared to } \\
\text { depressed and normal controls. SCZ and } \\
\text { SAD subjects, however, did not differ in } \\
\text { recall gain on this task. }\end{array}$ \\
\hline Roofeh et al 2006 & $\begin{array}{l}S C Z=37 \\
S A D=20 \\
\text { Controls }=60\end{array}$ & CVLT & $\begin{array}{l}\text { SAD and SCZ did not differ. Schizophrenic } \\
\text { spectrum was worse than age and } \\
\text { gender matched controls on measures } \\
\text { of apprehension, verbal learning, short- } \\
\text { term memory, long-term memory and } \\
\text { organizational strategies. }\end{array}$ \\
\hline
\end{tabular}


Table I (Continued)

\begin{tabular}{|c|c|c|c|}
\hline Reference & Population & Measures & Findings \\
\hline Brenner et al 2003 & $\begin{array}{l}S C Z=31 \\
S A D=11\end{array}$ & $\begin{array}{l}\text { Visual discrimination and recognition, } \\
\text { and tests of abstraction, verbal learning, } \\
\text { visual memory, working memory and } \\
\text { attention WCST, CVLT, CPT, and Family } \\
\text { Pictures }\end{array}$ & $\begin{array}{l}\text { Seven subjects with SCZ or SAD were } \\
\text { impaired on Family Pictures first recall. } \\
\text { Eight were impaired on Letter Number } \\
\text { Sequencing. WCST performance was } \\
\text { impaired in I } 2 \text { subjects. CVLT performance } \\
\text { was impaired in } 28 \text { subjects. CPT } \\
\text { performance was impaired in nine subjects. }\end{array}$ \\
\hline Bryson et al 2002 & $\begin{array}{l}S A D=14 \\
S C Z=28\end{array}$ & WCST, WAIS & $\begin{array}{l}\text { SCZ and SAD patients were below normal } \\
\text { at initial assessment. Reassessment } 3 \text { years } \\
\text { later did not show a decrease in function, } \\
\text { and } 20 \% \text { showed some improvement. }\end{array}$ \\
\hline Mitrushina et al 1996 & $\begin{array}{l}S C Z=21 \\
S A D=18 \\
\text { BMD I = } 18 \\
\text { MDD with Psychosis }=25 \\
\text { Psychotic DO NOS }=25\end{array}$ & $\begin{array}{l}\text { Neurobehavioral Cognitive Status } \\
\text { Examination }\end{array}$ & $\begin{array}{l}\text { SAD and SCZ had a deficit on "similarities' } \\
\text { scale suggesting a deficit in abstract } \\
\text { reasoning. SAD and SCZ also had a deficit } \\
\text { in terms of lowest spontaneous recall. }\end{array}$ \\
\hline Oltmanns et al 1985 & $\begin{array}{l}S C Z=10 \\
B M D I=11 \\
S A D=11 \\
M D D=10\end{array}$ & $\begin{array}{l}\text { Ratings of verbal communication } \\
\text { impairments }\end{array}$ & $\begin{array}{l}\text { SAD, SCZ and BMD subjects had more } \\
\text { derailment than normals and MDDs. SAD, } \\
\text { BMD and SCZ all had loss of goal and } \\
\text { decreased global rating compared with } \\
\text { normals and MDDs. }\end{array}$ \\
\hline Pope and Kern 2006 & $\begin{array}{l}\text { SCZ and SAD }=36 \\
\text { Controls }=22\end{array}$ & Word-stem completion task & $\begin{array}{l}\text { A measure of learning was applied to this } \\
\text { combined population of SCZ and SAD. } \\
\text { The combined group had more problems } \\
\text { with the task when errors where included } \\
\text { in the task. }\end{array}$ \\
\hline Stip et al 2005 & $\begin{array}{l}S A D=13 \\
S C Z=44\end{array}$ & $\begin{array}{l}\text { Motor Screening, reaction time, Paired } \\
\text { Associates Learning Task, and Stockings } \\
\text { of CANTAB items }\end{array}$ & $\begin{array}{l}\text { SCZ and SAD differed on visuo-motor } \\
\text { coordination and visuospatial substests, } \\
\text { with SAD subjects performing better than } \\
\text { subjects with SCZ. }\end{array}$ \\
\hline Kolakowska et al 1985 & $\begin{array}{l}S C Z=42 \\
S A D=14\end{array}$ & $\begin{array}{l}\text { Neurological 'soft' signs, CT scan } \\
\text { and cognitive impairment }\end{array}$ & $\begin{array}{l}\text { No relationship between the size of the } \\
\text { lateral brain ventricles on CT scan and } \\
\text { either 'soft' signs or cognitive impairment. }\end{array}$ \\
\hline
\end{tabular}

Abbreviations: SAD, schizoaffective disorder; SCZ, schizophrenia; BMD I, type I bipolar mood disorder; MDD, major depressive disorder; CVLT, California Verbal Learning Test; DRT, Spatial Delayed Response Task; WCST, Wisconsin Card Sort Test; CPT, Continuous Performance Task; WAIS, Wechsler Adult Intelligence Test; WMS, Wechsler Memory Scale; WTAR, Wechsler Test of Adult Reading; RAVLT, Rey Auditory Verbal Learning Test; BVMT, Brief Visual Memory Test; SSPI, Signs and Symptoms of Psychotic Illness; CT, computed tomography of the brain.

subjects with schizophrenia experienced greater deficits in posteriorly-mediated (ie, visuospatial) cognitive functions than persons with schizoaffective disorder (Stip et al 2005). Findings from the second of these studies may offer clarification on this observation: persons with schizoaffective disorder and paranoid schizophrenia were cognitively indistinguishable, but both groups differed cognitively from persons with undifferentiated and residual schizophrenia subtypes (Goldstein et al 2005). The authors argued that schizophrenia itself is a heterogeneous diagnosis; accordingly, subtyping of schizophrenia groups on the basis of the presence or absence of disturbances in other domains or severities of neurobehavioral dysfunction may result in separation between these clinical subgroups. Collectively, these observations suggest that when information processing (cognition) is the focus of study, persons with schizoaffective disorder are in most regards similar to those with schizophrenia.

\section{Structural neuroimaging (computerized tomography and magnetic resonance imaging)}

The neuroimaging literature of schizoaffective disorder is predominated by structural magnetic resonance imaging (MRI) studies, although diffusion tensor imaging, functional MRI, and magnetic resonance spectroscopy are emerging as additional methods of investigation (Table 2; Jurjus et al 1993; Cannon et al 1998; Bilder et al 1999; 
Table 2 Neuroimaging findings among studies of persons with schizoaffective disorder

\begin{tabular}{|c|c|c|c|}
\hline Reference & Population & Method & Findings \\
\hline Jurjus et al 1993 & $\begin{array}{l}\mathrm{SCZ}=67 \\
\mathrm{BMD} \text { and } \mathrm{SAD}=60 \\
\text { Controls }=37\end{array}$ & cMRI & $\begin{array}{l}\text { A higher frequency of cavum septum pellucidum was observed } \\
\text { among subjects with SCZ than among BMD and SAD subjects. No } \\
\text { clinical difference was found between SCZ with or without cavum } \\
\text { septum pellucidum. }\end{array}$ \\
\hline Prasad et al 2004 & $\begin{array}{l}\text { SCZ and SAD }=33 \\
\text { Non-SCZ psychotic } \\
\text { disorders = I I Controls }=43\end{array}$ & vMRI & $\begin{array}{l}\text { Left parahippocampal gyrus (PHG) was significantly smaller in subjects } \\
\text { with SCZ compared to non-SCZ psychotics but not controls. In } \\
\text { psychotic subjects, PHG volume negatively correlated with total } \\
\text { positive symptom, delusion and conceptual disorganization scores. } \\
\text { Patients with delusions had relatively smaller PHG compared to } \\
\text { nondelusional subjects. }\end{array}$ \\
\hline Buchanan et al 2004 & $\begin{array}{l}\text { SCZ and SAD }=44 \\
\text { Controls }=34\end{array}$ & vMRI & $\begin{array}{l}\text { Patients had smaller inferior prefrontal region volumes and reversal } \\
\text { of the normal asymmetry of the inferior parietal cortex. No } \\
\text { significant group differences were found in superior temporal gyrus } \\
\text { volume. }\end{array}$ \\
\hline Van Erp et al 2004 & $\begin{array}{l}\text { Probands with } S A D=12 \\
S C Z=60 \text { Proband siblings }=58 \\
\text { Controls }=53\end{array}$ & vMRI & $\begin{array}{l}\text { Decrease hippocampal volumes in probands compared to siblings. } \\
\text { Decrease volumes of siblings compared to normal controls. SAD } \\
\text { probands have diminshed hippocampal volumes with fetal hypoxia. } \\
\text { Decreased hippocampal volumes correlate positively with age at } \\
\text { onset for the combined SCZ and SAD group. }\end{array}$ \\
\hline Canon et al 2002 & $\begin{array}{l}\text { SCZ and SAD }=64 \\
\text { Ist degree relatives }=5 \mathrm{I} \\
\text { Controls }=54\end{array}$ & vMRI & $\begin{array}{l}\text { Fetal hypoxia predicted reduced gray matter and increased CSF } \\
\text { bilaterally throughout the cortex in patients and siblings, most } \\
\text { strongly in the temporal lobe. Hypoxia correlated significantly with } \\
\text { ventricular enlargement, but only among subjects with psychosis. }\end{array}$ \\
\hline Getz et al 2002 & $\begin{array}{l}\mathrm{SAD}=12 \\
\mathrm{BMD}=12 \text { Controls }=12\end{array}$ & VMRI & $\begin{array}{l}\text { SAD and BMD had significantly smaller cerebral volumes than } \\
\text { controls. Globus pallidal difference was the largest contribution } \\
\text { to this difference. }\end{array}$ \\
\hline Bilder et al 1999 & $\begin{array}{l}\text { Mood DO and SAD }=81 \\
\text { SCZ and SCZF }=87 \\
\text { Controls }=67\end{array}$ & VMRI & $\begin{array}{l}\text { A composite index of asymmetry across regions ('torque'), all } \\
\text { showed the same diagnostic group effect, with the SCZ group } \\
\text { showing least normal asymmetry, the mood DO group intermediate } \\
\text { asymmetry, and the control group the most asymmetry. }\end{array}$ \\
\hline Cannon et al 1998 & $\begin{array}{l}\text { SCZ }=62 \\
\text { SAD }=12 \\
\text { Nonpsychotic siblings }=60 \\
\text { Controls }=56\end{array}$ & vMRI & $\begin{array}{l}\text { Subjects with SCZ and SAD and their siblings exhibited significant } \\
\text { reductions in cortical gray matter volume and significant increases } \\
\text { in sulcal CSF volume compared with controls. The subjects, but not } \\
\text { their siblings, exhibited significant reductions in white matter volume } \\
\text { and significant increases in ventricular CSF volume. For subject and } \\
\text { sibling groups, gray matter volume reductions and sulcal CSF volume } \\
\text { increases were significantly most pronounced in the frontal and } \\
\text { temporal lobes. }\end{array}$ \\
\hline Szeszko et al 2005 & $\begin{array}{l}\text { First episode SAD }=5 \\
S C Z=5 \text { Controls }=13\end{array}$ & MRI-DTI & $\begin{array}{l}\text { Decrease left internal capsule and left-hemisphere white matter } \\
\text { of middle frontal gyrus and posterior superior temporal gyrus. }\end{array}$ \\
\hline Ardekani et al 2003 & $\begin{array}{l}\text { SCZ and SAD = } 14 \\
\text { Controls }=14\end{array}$ & MRI-DTI & $\begin{array}{l}\text { Abnormal white matter in corpus callosum, left superior temporal } \\
\text { gyrus, parahippocampal gyri, middle temporal gyri, inferior parietal } \\
\text { gyri, medial occipital lobe, and deep frontal perigenual region. }\end{array}$ \\
\hline Stone et al 2005 & $\begin{array}{l}S C Z=6 \\
S A D=2 \\
\text { All subjects with memory } \\
\text { deficits }\end{array}$ & fMRI & $\begin{array}{l}\text { Greater activation of the left parahippocampus in the glucose } \\
\text { condition, compared to the saccharin condition, despite no change } \\
\text { in memory performance. }\end{array}$ \\
\hline Keshavan et al 2003 & $\begin{array}{l}\text { SAD }=10 \\
S C Z=6 \\
\text { Controls }=37\end{array}$ & $P^{31} M R S$ & $\begin{array}{l}\text { Increase in psychotic subjects of freely mobile phosphomonoester } \\
\text { which is consistent with white matter changes in this group of } \\
\text { patients. }\end{array}$ \\
\hline
\end{tabular}

Abbreviations: SAD, schizoaffective disorder; SCZ, schizophrenia; BMD, bipolar mood disorder; Mood DO, mood disorder; SCZF, schizophreniform; cMRI, conventional magnetic resonance imaging; VMRI, volumetric magnetic resonance imaging; MRI-DTI, magnetic resonance imaging with diffusion tensor imaging; fMRI, functional magnetic resonance imaging; $\mathrm{P}^{31} \mathrm{MRS}$, phosphorus ${ }^{31}$ magnetic resonance spectroscopy. 
Cannon et al 2002; Getz et al 2002; Ardekani et al 2003; Keshavan et al 2003; Buchanan et al 2004; Prasad et al 2004; Van Erp et al 2004; Stone et al 2005; Szeszko et al 2005). In general, these studies have found that schizoaffective disorder is associated with reductions in cerebral volumes, particularly temporal (including medial temporal) and frontal regions, including both gray and white matter. The most consistent areas of abnormality across these studies are the hippocampus and parahippocampal gyri. Subjects with schizoaffective disorder are generally found to be similar to the other diagnostic group in which they are included (ie, schizophrenia or bipolar disorder) and different from healthy comparison subjects; when comparisons are made between schizophrenia and schizoaffective disorder, few differences are evident. These observations echo our earlier suggestion that the focus of the neurobehavioral dimension under study (information processing or emotional regulation) tends to predict both similarities and differences between subjects with schizoaffective disorder, schizophrenia, and mood disorders.

\section{Electrophysiology}

Schizoaffective disorder is associated with abnormal eventrelated potentials (P50, N100, N400, CNV, and others), localization of sensory evoked magnetic fields, middle ear muscle activity, and eye movements (Table 3; Benson and Zarcone 1982; Goode and Manning 1985; Saccuzzo and Braff 1986; Borenstein et al 1988; Lieberman et al 1993b; Keshaven et al 1995; Benson et al 1996; Boutros et al 1997; Bruder et al 1998; Inui et al 1998; Reite et al 1999; Kayser et al 1999, 2001; Teale et al 2000; Brenner et al 2003; Kathmann et al 2003; Kumar and Debruille 2004; Olincy and Martin 2005). Subjects with schizoaffective disorder were primarily contrasted with subjects with either schizophrenia or bipolar disorder with psychotic features. Boutros and colleagues (1997) and Inui and colleagues (1998) published studies which suggest more similarity between schizoaffective disorder and bipolar disorder with psychotic features than with schizophrenia. As with other categories in this review the strength of the literature limits the conclusions we can make regarding the electrophysiological distinction between these conditions. However, these studies do suggest that psychosis (ie, information processing impairment), regardless of categorical psychiatric diagnosis and its expression as persistent or mood-episode-related, is associated with electrophysiologic abnormalities. This observation also argues for a dimensional approach to the study of electrophysiologic indices of information processing abnormalities rather than a categorical diagnostic approach.

\section{Neuroendocrine function}

There are only three studies to-date, all of which evaluated differences in growth hormone levels, that evaluate neurohormonal changes in schizoaffective disorder (Table 4; Kumar et al 1993; Lieberman et al 1993b; Mokrani et al 2000). Mokrani and colleagues (2000) studied growth hormone responses to clonidine challenge among subjects with schizoaffective disorder, schizophrenia, and major depressive disorder. They observed similar responses between subjects with schizophrenia and healthy comparison subjects and similar responses between schizoaffective subjects and those with major depressive disorder. By contrast, Kumar and colleagues (1993) and Lieberman and colleagues (1993a) demonstrated similarities in growth hormone response to pharmacologic treatment in patients with psychosis and emotional regulation disturbances regardless of categorical psychiatric diagnosis. Although this literature is not developed sufficiently to permit firm conclusions, it appears that neuroendocrine disturbances are more closely related to dysfunction in either the information processing domain, emotional regulation domain, or both, than to categorical diagnosis. One would predict that other neuroendocrine abnormalities, and particularly those assessing the hypothalamic - pituitary - adrenal axis, might be more closely related to disturbances in emotional regulation than to information processing abnormalities. As reiterated below, focusing future investigations along dimensional lines might facilitate identification of neuroendocrine abnormalities than does a categorical diagnostic approach.

\section{Neurochemical function}

Studies of neurotransmitter function that include persons with schizoaffective disorder are few, and consist primarily of observational studies of cerebrospinal fluid (CSF) or serum neurotransmitter metabolites. In an earlier review, Meltzer and colleagues (1984) reported similar patterns of neurochemical abnormalities among persons with schizophrenia, bipolar disorder, and schizoaffective disorder. In that review, it was reported that CSF norepinephrine, prostaglandin E1, norepinephrine and PGE1 adenyl cyclase and platelet 5HT levels among persons with schizophrenia and schizoaffective disorder are similar, while platelet 5HT profiles are more alike among persons with bipolar disorder and schizoaffective disorder than those with schizophrenia. Subsequent studies of these sorts (Table 5; Laruelle et al 1993; Sharma et al 1993, 1994, 1995, 1997, 1998; Faustman et al 1999) have generally observed no differences between persons with these conditions; instead, neurotransmitter 
Table 3 Electrophyiologic studies of persons with schizoaffective disorder

\begin{tabular}{|c|c|c|c|}
\hline Reference & Population & Method & Findings \\
\hline $\begin{array}{l}\text { Olincy and } \\
\text { Martin } 2005\end{array}$ & $\begin{array}{l}\mathrm{BMD}=42 \\
\mathrm{SAD}=22 \\
\text { Controls }=42\end{array}$ & $\begin{array}{l}\text { ERPs P50 auditory } \\
\text { evoked potential }\end{array}$ & $\begin{array}{l}\text { SAD and BMD with psychosis demon- } \\
\text { strated higher P50 ratios (nonsuppres- } \\
\text { sion) compared to controls and BMD } \\
\text { subjects without a history of psychosis. }\end{array}$ \\
\hline $\begin{array}{l}\text { Kumar and } \\
\text { Debruille } 2004\end{array}$ & SCZ and SAD & $\begin{array}{l}\text { Review of } 10 \text { studies of } \mathrm{N} 400 \\
\text { amplitude in these populations }\end{array}$ & $\begin{array}{l}\text { Diminished N400 amplitude in SCZ } \\
\text { and SAD. }\end{array}$ \\
\hline Brenner et al 2003 & $\begin{array}{l}\mathrm{SCZ} \text { and SAD }=23 \\
\text { Controls }=22\end{array}$ & $\begin{array}{l}\text { ERPs sensory NI00 and EEG } \\
\text { synchronization to modulated } \\
\text { auditory tones }\end{array}$ & $\begin{array}{l}\text { SCZ and SAD have decreased power in } \\
\text { steady-state responses to periodic stimuli, } \\
\text { despite normal NI00 responses. }\end{array}$ \\
\hline Kayser et al $200 \mathrm{I}$ & $\begin{array}{l}S C Z=46 \\
S A D=20 \\
\text { Controls }=32\end{array}$ & ERPs tonal and oddball tasks & $\begin{array}{l}\text { Patients showed marked, task-independent } \\
\text { reductions of early negative potentials. } \\
\text { Task-related hemispheric asymmetries } \\
\text { were similar in healthy adults and subjects. }\end{array}$ \\
\hline Kayser et al 1999 & $\begin{array}{l}S C Z=16 \\
S A D=8 \\
\text { Controls }=19\end{array}$ & $\begin{array}{l}\text { ERPs of a continuous word } \\
\text { recognition memory task }\end{array}$ & $\begin{array}{l}\text { Accuracy of word recognition memory } \\
\text { was poorer in subjects than controls, and } \\
\text { subjects showed markedly smaller N2 } \\
\text { amplitude. Among controls, asymmetry } \\
\text { was not present in patients and suggested } \\
\text { a left lateralized deficit among subjects. }\end{array}$ \\
\hline Bruder et al 1998 & $\begin{array}{l}S C Z=19 \\
S A D=9 \\
\text { Controls }=28\end{array}$ & $\begin{array}{l}\text { ERPs during a dot } \\
\text { enumeration task }\end{array}$ & $\begin{array}{l}\text { Subjects showed poorer dot enumeration } \\
\text { than did controls and also had markedly } \\
\text { reduced early negative ERPs. }\end{array}$ \\
\hline Boutros et al 1997 & $\begin{array}{l}\mathrm{SAD}=19 \\
\mathrm{SCZ}=50 \\
\mathrm{BMD}=16 \\
\text { Controls }=41\end{array}$ & $\begin{array}{l}\text { ERPs }- \text { P50 } \\
\text { NI } 00 \text { oddball, } \\
\text { P200 } \\
\text { P300 }\end{array}$ & $\begin{array}{l}\text { SAD had significant decrease in P200 } \\
\text { compared with controls and SCZ (but } \\
\text { not BMD) and otherwise did not separate } \\
\text { from other groups. }\end{array}$ \\
\hline Borenstein et al 1988 & $\begin{array}{l}S C Z=27 \\
S A D=13 \\
\text { Controls }=27\end{array}$ & $\begin{array}{l}\text { ERPs - CNV } \\
\text { (contingent negative variation) }\end{array}$ & $\begin{array}{l}\text { Pre- and post-imperative phases of } \\
\text { the CNV were heterogeneous in } \\
\text { character suggesting the possibility of } \\
\text { multiple disturbances. When present, } \\
\text { the pre-imperative negativity was of } \\
\text { lower amplitude and had a delayed return } \\
\text { to the baseline with a wider dispersion. }\end{array}$ \\
\hline $\begin{array}{l}\text { Saccuzzo and } \\
\text { Braff } 1986\end{array}$ & $\begin{array}{l}S C Z=11 \\
S A D=11 \\
B M D=11 \\
M D D=11\end{array}$ & $\begin{array}{l}\text { ERPs - visual masking paradigm } \\
\text { assessing response at } 500 \mathrm{msec} \\
\text { post-stimulus }\end{array}$ & $\begin{array}{l}\text { MDD was different than SAD, BMD and } \\
\text { SCZ in some measures of this paradigm. }\end{array}$ \\
\hline Inui et al 1998 & $\begin{array}{l}S C Z=33 \\
S A D=12 \\
\text { Mood-incongruent } \\
\text { psychotic mood disorder }=12 \\
\text { nonpsychotic mood disorder }=62 \\
S C Z F=12\end{array}$ & EEG & $\begin{array}{l}\text { Increased epileptiform variants in } \\
\text { mood-incongruent psychotic mood } \\
\text { disorder (33\%), SAD ( } 33 \%) \text {, and SCZF } \\
(30 \%) \text {, compared with nonpsychotic } \\
\text { mood disorder ( } 3.2 \%) \text { and SCZ (0\%). }\end{array}$ \\
\hline Benson et al 1996 & $\begin{array}{l}S A D=3 \\
S C Z=11\end{array}$ & $\begin{array}{l}\mathrm{EEG} \text { and } \mathrm{CT} \text { measures of } \\
\text { ventricular volume }\end{array}$ & $\begin{array}{l}\text { Deficits in slow wave sleep correlated } \\
\text { with ventricular volume }\end{array}$ \\
\hline Keshaven et al 1995 & $\begin{array}{l}S C Z=12 \\
S A D=8\end{array}$ & EEG - slow-wave delta sleep & $\begin{array}{l}\text { Decreased percentage of delta sleep } \\
\text { significantly correlated with poorer } \\
\text { clinical outcomes at I and at } 2 \text { years. }\end{array}$ \\
\hline $\begin{array}{l}\text { Benson and Zarcone } \\
1982\end{array}$ & $\begin{array}{l}S C Z=11 \\
S A D=8 \\
M D D=10 \\
\text { Controls } 13\end{array}$ & $\begin{array}{l}\text { Rate of middle ear muscle } \\
\text { activity during REM sleep }\end{array}$ & $\begin{array}{l}\text { Middle ear muscle activity was lowest } \\
\text { for SAD, than normal patients, than } \\
\text { depressed and highest for SCZ patients. }\end{array}$ \\
\hline Teale et al 2000 & $\begin{array}{l}S C Z=14 \\
S A D=12 \\
\text { Controls }=23\end{array}$ & $\begin{array}{l}\text { MEG - Localization of } \\
\text { magnetic sources for auditory } \\
\text { MI00 signals }\end{array}$ & $\begin{array}{l}\text { SAD and SDZ exhibited different source } \\
\text { localization in auditory cortex compared } \\
\text { to one another and controls. }\end{array}$ \\
\hline
\end{tabular}


Table 3 (Continued)

\begin{tabular}{|c|c|c|c|}
\hline Reference & Population & Method & Findings \\
\hline Reite et al 1999 & $\begin{array}{l}S A D=16 \\
\text { Controls }=16\end{array}$ & $\begin{array}{l}\text { Magnetoencephalography } \\
\text { (MEG) M20 for median nerve } \\
\text { stimulation }\end{array}$ & $\begin{array}{l}\text { Reversed asymmetry of M20 in SAD } \\
\text { located on the post-central gyrus in this } \\
\text { disorder. }\end{array}$ \\
\hline Kathmann et al 2003 & $\begin{array}{l}S C Z \text { and } S A D=54 \\
\text { Affective } D O=43 \\
\text { Relatives: } \text { Psychosis }=43 \\
\text { Affective } D O=36 \\
\text { Controls }=84\end{array}$ & Eye tracking tasks & $\begin{array}{l}\text { Decreased eye pursuit gain in } \mathrm{SCZ} \text { and } \\
\text { affective disorders. This deficit is present, } \\
\text { to a lesser extent, in their relatives. }\end{array}$ \\
\hline Lieberman I993 & $\begin{array}{l}S A D=16 \\
S C Z=54\end{array}$ & Eye movement tracking & $\begin{array}{l}\text { Morphologic abnormalities of the medial } \\
\text { temporal lobe and third ventricle were } \\
\text { associated with normal eye tracking } \\
\text { suggesting changes in SAD and SCZ are } \\
\text { part of the disease process not pathologic } \\
\text { changes. }\end{array}$ \\
\hline $\begin{array}{l}\text { Goode and } \\
\text { Manning } 1985\end{array}$ & $S A D=10$ & $\begin{array}{l}\text { EMG - Hoffmann reflex } \\
\text { recovery }\end{array}$ & $\begin{array}{l}\text { Right-left differences in Hoffmann reflex } \\
\text { (H reflex) recovery curve height signifi- } \\
\text { cantly correlated with standardized scales } \\
\text { of psychopathology. }\end{array}$ \\
\hline
\end{tabular}

Abbreviations: SAD, schizoaffective disorder; SCZ, schizophrenia; BMD, bipolar mood disorder; Mood DO, mood disorder; MDD, major depressive disorder; SCZF, schizophreniform; ERP, event-related potential; EEG, electroencephalography; CT, computed tomography; REM, rapid eye movement; MEG, magnetoencephalography; EMG, electromyography.

abnormalities are more strongly associated with symptom severity (and particularly psychosis) as well as outcome measures (ie, length of hospitalization). Again, a dimensional approach to the study of these populations appears to inform more usefully on cerebral neurochemical abnormalities than categorical psychiatric diagnosis.

\section{Genetics}

There have been few studies performed with the intent of identifying genetic differences between persons with schizoaffective disorder and other major psychiatric disorders. Instead, most studies have grouped subjects with schizoaffective disorder among those with either schizophrenia or bipolar disorder depending on the dimension of neurobehavioral dysfunction (ie, information processing or emotional regulation) emphasized by the investigators (Table 6; Weiss et al 1996; Cardno et al 2001; Ujike et al 2001; Dick et al 2003; Segurado et al 2003; Skol et al 2003; Wijsman et al 2003; Willour et al 2003; Giouzeli et al 2004; Hodgkinson et al 2004; Kirov et al 2004; Hamshere et al 2005; Liu et al 2005; Staddon et al 2005; DeLisi et al 2002; Faraone et al 2002). As with other types of neurobiological investigations, these studies have generally failed to distinguish schizoaffective disorder from either schizophrenia or bipolar disorder on the basis of their genetic underpinnings. Hodgkinson and colleagues (2004) report that schizoaffective disorder, has an underrepresentation of a common haplotype from the intron 1/exon 2 region of DISC1 (on chromosome 1q42), as well as overrepresentation of the DISC1 exon 9 missense allele Phe607. The potential importance of this particular abnormality of DISC1 follows from the need to identify a mechanism by which dysfunction in both the information processing and emotional regulation dimensions of neurobehavioral function are produced (Hodgkinson et al 2004; Ishizuka et al 2006; Porteous et al 2006).

DISC1 (an acronym for Disrupted-In-Schizophrenia-1) appears to play a role in neurodevelopment and is preferentially expressed in the forebrain. Posttranslational modification produce multiple isoforms of this protein. DISC1 protein is expressed in multiple intracellular compartments, including the nucleus, centrosome, mitochondria, microtubule fractions, actin cytoskeletal fractions, and postsynaptic densities, Among the possible functions of DISC1, mediation of centrosome-dynein cascade and cyclic adenosine monophosphate (cAMP) signaling have been described. DISC1 also interacts with other proteins that may mediate neurobehavioral function, including Ndel1 and PDE4B. The former regulates neuronal migration via endo-oligopeptidase activity, and the latter is a phosphodiesterase involved in cyclic adenosine monophosphate signaling. PDE4B is of particular interest in that it is linked to both information processing (memory) and emotional regulation.

Abnormalities of DISC1 are regarded as potential genetic risk factors for both schizophrenia and bipolar disorder 
Table 4 Neuroendocrine studies of persons with schizoaffective disorder

\begin{tabular}{|c|c|c|c|}
\hline Reference & Population & Method & Findings \\
\hline Mokrani et al 2000 & $\begin{array}{l}S A D=31 \\
S C Z=16 \\
M D D=87 \\
\text { Controls }=22\end{array}$ & $\begin{array}{l}\text { Growth hormone } \\
\text { responses to the } \\
\text { clonidine challenge }\end{array}$ & $\begin{array}{l}\text { Lower GH response to stimulation with } \\
\text { clonidine among MDD and SAD subjects } \\
\text { when compared to SCZ subjects and } \\
\text { controls. }\end{array}$ \\
\hline Kumar and Marks 1993 & $\begin{array}{l}\text { Post-partum and } \\
\text { a history of BMD or SAD } \\
S C Z=46 \\
S A D=19 \\
M D E=50 \\
\text { Controls }=18\end{array}$ & $\begin{array}{l}\text { Growth hormone } \\
\text { responses to clonidine and } \\
\text { apomorphine challenge }\end{array}$ & $\begin{array}{l}\text { Increased growth hormone response to } \\
\text { apomorphine challenge test compared to } \\
\text { those who remained well and to controls } \\
\text { Life events history did not influence these } \\
\text { findings. }\end{array}$ \\
\hline Lieberman et al 1993 & $\begin{array}{l}\text { SAD }=16 \\
S C Z=54 \\
\text { Controls }=50\end{array}$ & $\begin{array}{l}\text { GH secretion in response } \\
\text { to methyphenidate } \\
\text { challenge }\end{array}$ & $\begin{array}{l}\text { Abnormal GH secretion and decreased } \\
\text { GH response to methylphenidate in the } \\
\text { subjects with psychosis. }\end{array}$ \\
\hline
\end{tabular}

Abbreviations: SAD, schizoaffective disorder; SCZ, schizophrenia; BMD, bipolar mood disorder; MDD, major depressive disorder; MDE, major depressive episode; $\mathrm{GH}$, growth hormone.

Table 5 Neurochemical studies of persons with schizoaffective disorder

\begin{tabular}{|c|c|c|c|}
\hline Reference & Population & Method & Findings \\
\hline Faustman 1999 & $\begin{array}{l}\text { Medication-free } \\
\text { males with: } \\
S C Z=13 \\
S A D=6\end{array}$ & CSF glutamate & $\begin{array}{l}\text { Ratings of positive symptoms were inversely correlated } \\
\text { with CSF glutamate concentrations. Hallucinatory } \\
\text { behavior was strongly correlated with CSF glutamate } \\
\text { concentrations. In a subset of subjects who received } \\
\text { haloperidol, haloperidol did not alter CSF glutamate } \\
\text { concentrations and symptoms no longer correlated } \\
\text { with CSF glutamate levels. }\end{array}$ \\
\hline Sharma et al I 998 & $\begin{array}{l}\text { Inpatients with: } \\
S C Z=33 \\
S A D=21\end{array}$ & Plasma HVA & $\begin{array}{l}\text { Correlation between length of inpatient stay and } \\
\text { plasma HVA levels. }\end{array}$ \\
\hline Sharma et al 1993 & $\begin{array}{l}\text { Inpatients with: } \\
S C Z=15 \\
S A D=4\end{array}$ & CSF - HVA & $\begin{array}{l}\text { Plasma homovanillic acid levels correlated with length } \\
\text { of inpatient treatment but not other measures or } \\
\text { group differences. }\end{array}$ \\
\hline Sharma et al I 997 & $\begin{array}{l}\text { Inpatients with: } \\
S C Z=29 \\
S A D=13\end{array}$ & CSF neurotensin & $\begin{array}{l}\text { Neurotensin levels were decreased pre-treatment in } \\
\text { both SAD and SCZ subjects. Lower neurotensin levels } \\
\text { pre-treatment were associated with increased severity } \\
\text { of psychopathology. Neurotensin levels increased with } \\
\text { treatment. }\end{array}$ \\
\hline Sharma et al 1995 & $\begin{array}{l}\text { SAD, SCZ, BMD } \\
\text { (either manic or } \\
\text { depressed) }=16\end{array}$ & CSF phenylacetic acid & $\begin{array}{l}\text { No difference in CSF phenylacetic acid levels } \\
\text { as a function of psychiatric diagnosis. }\end{array}$ \\
\hline Sharma et al I 994 & $\begin{array}{l}\text { Inpatients with: } \\
S A D=3 \\
S C Z=14\end{array}$ & CSF somatostatin & $\begin{array}{l}\text { Duration of treatment correlated with CSF } \\
\text { somatostatin levels, but there were no differences } \\
\text { between subject groups. }\end{array}$ \\
\hline Laruelle et al 1993 & $\begin{array}{l}S C Z=12 \\
S A D=9 \\
\text { Nonpsychotic } \\
\text { suicide victims }=9 \\
\text { Controls }=16\end{array}$ & $\begin{array}{l}\text { Post-mortem } \\
\text { serotonin receptors }\end{array}$ & $\begin{array}{l}\text { Serotonin uptake sites were decreased in prefrontal } \\
\text { cortex of psychotic subjects who died of natural causes, } \\
\text { but not among psychotics who died from suicide, } \\
\text { controls, and nonpsychotic suicide victims. }\end{array}$ \\
\hline
\end{tabular}

Abbreviations: SAD, schizoaffective disorder; SCZ, schizophrenia; BMD, bipolar mood disorder; HVA, homovanillic acid; 5-HT, serotonin; PGEI, prostaglandin $E_{1}$ stimulated adenylate cyclase activity; NE, norepinephrine; GABA, gamma-aminobutyric acid. 
Table 6 Genetic studies of persons with schizoaffective disorder

\begin{tabular}{|c|c|c|c|}
\hline Reference & Population & Genetic linkage & Ethnicity/Geography \\
\hline Hamshere et al 2005 & $\mathrm{SAD}=35$ & $\begin{array}{l}\text { Suggestive linkage on chromosomes } \\
|q 42,22 q||,| 9 p \mid 3 \text {. }\end{array}$ & United Kingdom \\
\hline Liu et al 2005 & $S C Z$ and $S A D=52$ & $\begin{array}{l}\text { Suggestive linkage of neuregulin I (NRGI) } \\
\text { on chromosome 8p2I (NRGI is an isoform } \\
\text { of glial growth factor 2). }\end{array}$ & Taiwanese family \\
\hline Staddon et al 2005 & $\begin{array}{l}S C Z=105 \\
S A D=13 \\
\text { Controls }=162\end{array}$ & $\begin{array}{l}\text { Increase in dopamine D3 receptor gene } \\
\text { alleles-7685-C, SeaGly and } 205 \text { G/A. }\end{array}$ & Basque family \\
\hline Giouzeli et al 2004 & $\begin{array}{l}\text { SCZ and SAD = } 294 \text { Families } \\
\text { containing } 2 \text { members with } \\
\text { these diagnoses }\end{array}$ & $\begin{array}{l}\text { Neither the coding variants nor the intron } \\
\text { polymorphisms of protocadherin } X / Y \text { are } \\
\text { related to psychosis within families. }\end{array}$ & United Kingdom \\
\hline Hodgkinson et al 2004 & $\begin{array}{l}\mathrm{SAD}=62 \\
\mathrm{SCZ}=196 \\
\mathrm{BMD}=82 \\
\text { Controls }=17\end{array}$ & $\begin{array}{l}\text { SAD has decrease of the common haplotype } \\
\text { of intron I/exon } 2 \text { of DISCI. In addition, } \\
\text { SAD has an increase in exon } 9 \text {. Multiple } \\
\text { haplotypes between exon I and } 9 \text { are associ- } \\
\text { ated with SCZ, SAD and BMD. (DISCI gene, } \\
\text { on chromosome Iq42, was discovered and } \\
\text { linked to schizophrenia in a Scottish kindred } \\
\text { carrying a translocation). }\end{array}$ & United States \\
\hline Kirov et al 2004 & $\begin{array}{l}\text { Parents of probands with: } \\
S C Z=44 I \\
S A D=47\end{array}$ & $\begin{array}{l}\text { Increase in DTNBPI markers } \\
\text { pI635 and p I } 1757 .\end{array}$ & Bulgaria \\
\hline Skol et al 2003 & $\begin{array}{l}S C Z=361 \\
S A D=31\end{array}$ & Increase in NOTCH4 at 6p21.3. & United States veterans \\
\hline Willour et al 2003 & $\begin{array}{l}B M D I=134 \\
B M D \|=4 I \\
S A D=5 \\
M D D=43\end{array}$ & $\begin{array}{l}\text { Large predominant bipolar pedigree } \\
\text { had linkages at } 4 \mathrm{q} 35 \text {, } 4 \mathrm{q} 32 \text { and } 20 \mathrm{p} I 2 .\end{array}$ & $\begin{array}{l}\text { United States } \\
\text { BMD pedigrees }\end{array}$ \\
\hline Dick et al 2003 & $\begin{array}{l}\text { BMD I = } 232 \\
\text { SAD/Bipolar type }=32 \\
\text { BMD II = } 72 \text { MDD = } 88, \\
\text { recurrent and siblings. }\end{array}$ & $\begin{array}{l}\text { Large predominant bipolar pedigree with } \\
\text { linkage greatest at } 17 \mathrm{q}, 6 \mathrm{q} \text {, and less at } 2 \mathrm{p} \text {, } \\
3 \mathrm{q} \text { and } 8 \mathrm{q} \text {. The less strong linkages included } \\
\text { patients with less severe BMD and MDD. }\end{array}$ & United States \\
\hline Segurado et al 2003 & $\begin{array}{l}\text { BMD }=2300 \text { cases, } \\
617 \text { pedigrees and spectrum } \\
\text { SAD/Bipolar }=82\end{array}$ & $\begin{array}{l}\text { Findings were not significant } \\
\text { on } 13 q \text { or } 22 q \text {. }\end{array}$ & Ireland \\
\hline Wijsman et al 2003 & $\mathrm{SCZ}$ and $\mathrm{SAD}=32$ & $\begin{array}{l}\text { Linkage at } 2 q 37 \text { in a population } \\
\text { of reduced heterogeneity. }\end{array}$ & Micronesia \\
\hline Faraone et al 2002 & $\begin{array}{l}\text { Family members of subjects with: } \\
\mathrm{SCZ}=360 \\
\mathrm{SAD}=32\end{array}$ & Linkage at $13 q 32$. & United States veterans \\
\hline DeLisi et al 2002 & $\begin{array}{l}\text { SCZ and SAD }=294 \text { Families } \\
\text { containing at least } 2 \text { members } \\
\text { with these diagnoses }\end{array}$ & Linkage on chromosome $5 q$ & Costa Rica \\
\hline Cardno et al 2001 & $\begin{array}{l}\text { Sibling pairs with either SCZ } \\
\text { or SAD. Total }=94\end{array}$ & $\begin{array}{l}\text { Six areas of possible relationship } \\
\text { of age of onset of schizophrenia } \\
\text { to specific } 20 \mathrm{cM} \text { areas of DNA in I3q }\end{array}$ & United Kingdom \\
\hline Ujike et al 200I & $\begin{array}{l}S C Z=188 \\
S A D=3 \\
\text { Controls }=143\end{array}$ & NOTCH4 at 6p21.3 not significant in Japan. & Japan \\
\hline Weiss et al 1996 & $\begin{array}{l}S C Z=91 \\
S A D=20 \\
M D D / \text { dysthymia }=90\end{array}$ & $\begin{array}{l}\text { Increase in frequency of D } 4.7 \text { allele and } \\
\text { DRD4 polymorphism in patients with } \\
\text { psychosis. }\end{array}$ & Germany \\
\hline
\end{tabular}

Abbreviations: SAD, schizoaffective disorder; SCZ, schizophrenia; BMD, bipolar mood disorder; BMD I, type I bipolar mood disorder; BMD II, type II bipolar mood disorder; MDD, major depressive disorder; DNA, deoxyribonucleic acid. 
(Ishizuka et al 2006). The findings of Hodgkinson and colleagues (2004) suggest the possiblility that particular abnormalities of this gene, or the manner in which its product undergoes posttranslational modification, may produce dysfunction in both information processing and emotional regulation. In some cases, these disturbances may affect information processing more so than emotional regulation (producing the phenotype of schizophrenia with minor mood disturbances), in others the emotional regulation dimension may be more severely affected (bipolar disorder), or severe disturbances in both of these neurobehavioral domains (ie, schizoaffective disorder). It is unlikely that disturbances in DISC1 are the only, or perhaps even the primary, genetic basis for the severe multidimensional neurobehavioral dysfunction observed among persons presently identified with schizoaffective disorder rather than schizophrenia or bipolar disorder. However, such data suggest the possibility that the neurobiological bases of information processing and emotional regulation may have distinct genetic contributions that in some cases may be linked (as by specific abnormalities of DISC1) and thereby produce severe problems in both of these neurobehavioral domains. If this thesis is correct, it suggests that the categorical approach to psychiatric diagnosis will ultimately fail as a useful psychiatric nosology and that a dimensional approach, perhaps predicated on the genetics of specific neurobehavioral domains, to the study and treatment of persons with neurobehavioral disorders will prove more productive.

\section{Treatment}

Although inferential reasoning regarding diagnosis and neurobiology from pharmacologic treatment studies is ill-advised, it is noteworthy that treatment approaches to schizoaffective disorder echo the dimensional approach suggested here. Despite the identification of schizoaffective disorder as a distinct diagnosis in the DSM-based system, there are no treatments specific for this condition. Instead, symptom-guided treatment approaches are generally advocated for persons with this conditions. Table 7 (Keck et al 1996; Levinson et al 1999; McElroy et al 1999; Vieta et al 2001; Tohen et al 2001; Bilder et al 2002; Sajatovic et al 2002; Chengappa et al 2003; Harvey et al 2003, 2004; Marder et al 2003; Baethge et al 2004; Davis and Chen 2004) summarizes a sample of treatment studies in which patients with schizoaffective disorder are included; Few of these publications emphasize the treatment of schizoaffective disorder alone, and where this disorder is the focus of study it appears that symptom profile along dimensional lines (information processing vs emotional regulation vs both), rather than subtype of this diagnosis, determines treatment recommendations.

\section{Conclusion}

The challenge of describing schizoaffective disorder within a psychiatric nosology that requires categorical distinctions between diagnostic entities is substantial. Using a categorical diagnostic approach, the data reviewed herein suggests that schizoaffective disorder can be argued with nearly equal merit to be a variant of either schizophrenia or a mood (and particularly bipolar) disorder, a condition in which schizophrenia and a mood disorder are co-morbid, or a unique psychiatric disorder. This conclusion, however unsatisfying, appears to be unavoidable if a categorical approach to psychiatric diagnosis is undertaken. Moreover, the present review suggests that the challenges schizoaffective disorder presents to categorical psychiatric diagnosis are not unique to this condition, but are instead pervasive in psychiatric research and practice. Although most studies begin with the premise that schizophrenia and bipolar disorder are distinct conditions, the observation of minor mood disturbances among persons with the former and often severe psychosis among those with the latter should raise concerns about the certainty of clear diagnostic boundaries between them. The consistent observation of neuroimaging, electrophysiologic, neurochemical, neuroendocrine, genetic, and treatment findings that more effectively follow psychiatric symptoms rather than categorical diagnoses suggests that the former, and not the latter, may be the more useful focus of both psychiatric research and clinical practice.

Indeed, the present review suggests that the study, evaluation, and treatment of persons with psychiatric disorder is likely to be most productive when anchored to the dimensions of neurobehavioral dysfunction with which they present. This approach, which derives from the approach used in behavioral neurology and neuropsychiatry, begins with the premise that cognition, emotion, behavior, and sensorimotor function are distinct but interrelated domains of neurobehavioral function (Arciniegas and Kaufer 2006). Regardless of the clinical condition (eg, stroke, trauma, neurodegenerative disease, idiopathic psychiatric illness) producing disturbances in these neurobehavioral domains, it is posited that their neuroanatomic and neurochemical bases are likely to be similar despite differences in the conditions disturbing brain structure and function. It is further suggested that there may be etiology-specific neuroanatomic, neurochemical, neuroendocrine, or genetic features of the 


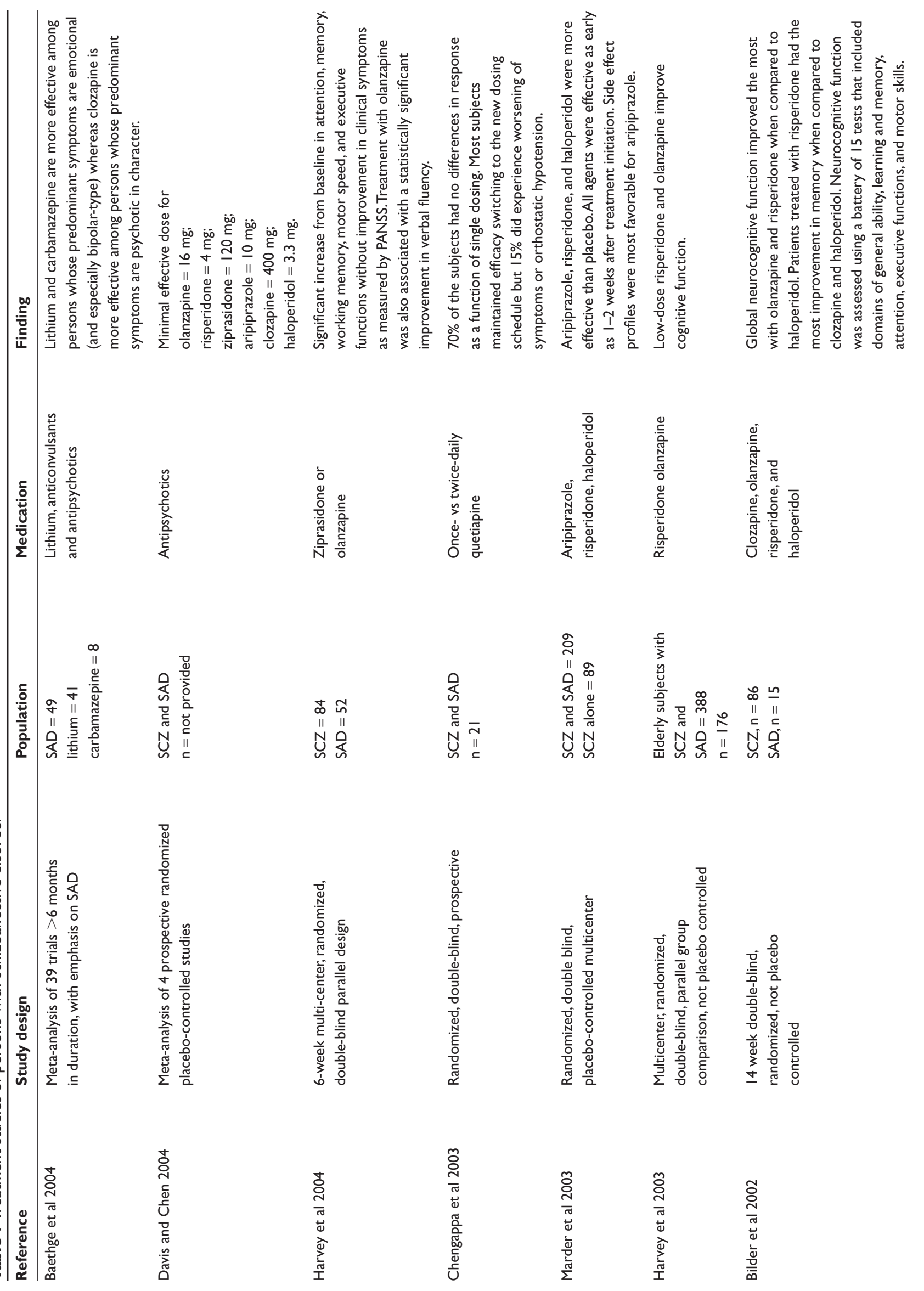



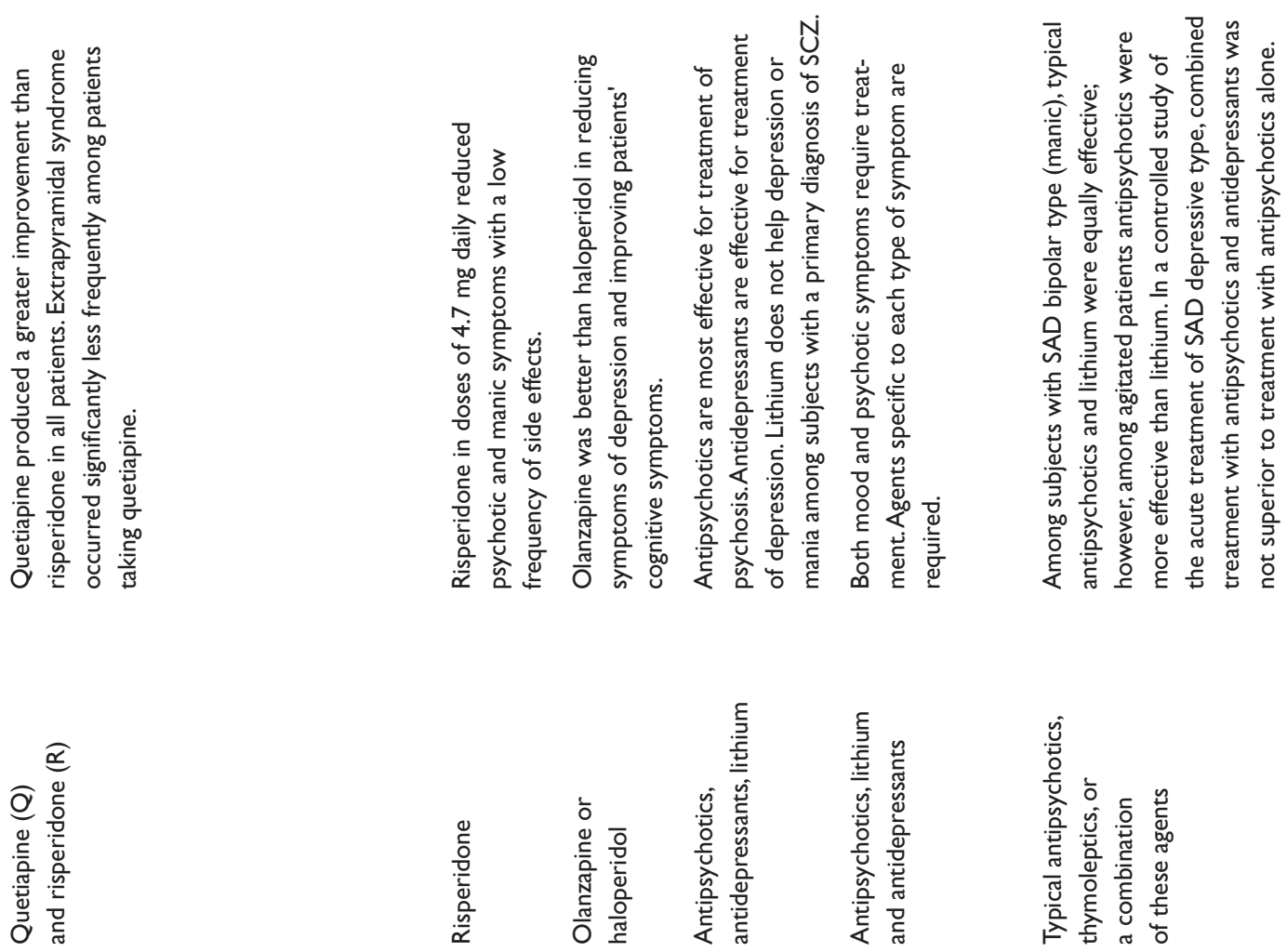

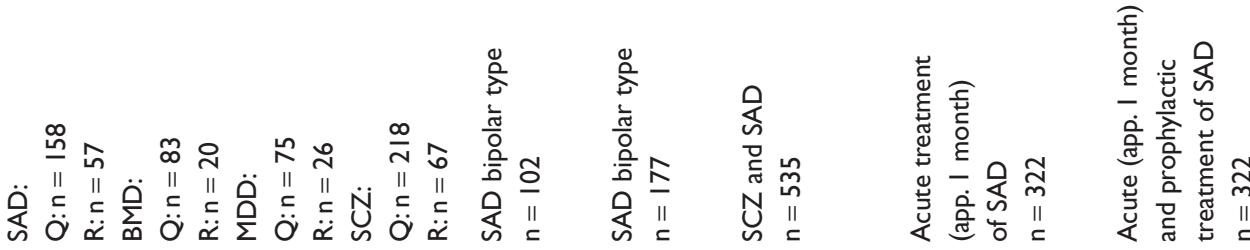
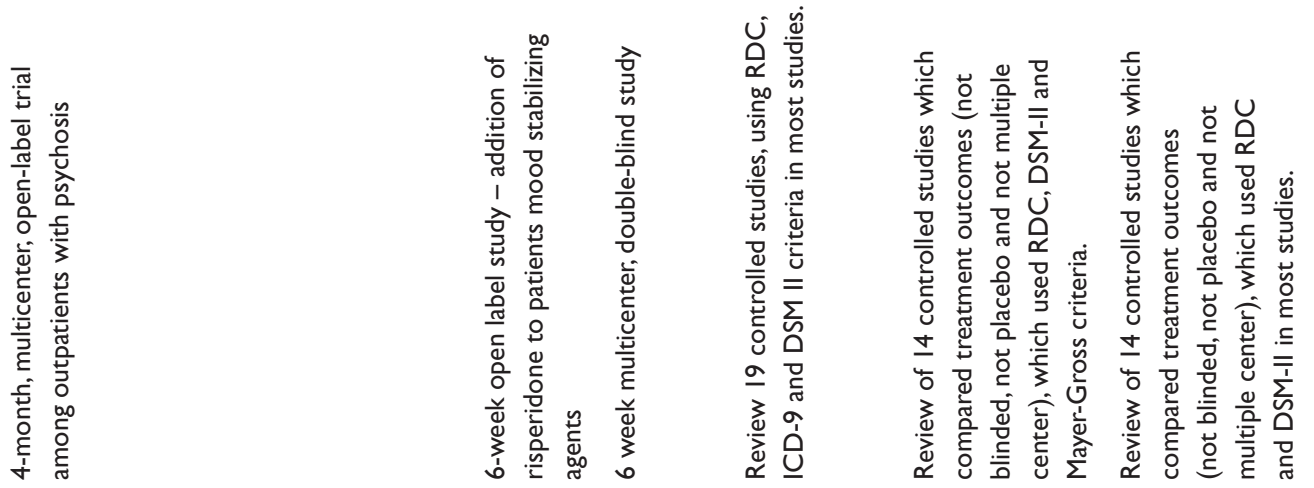

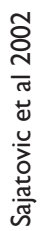

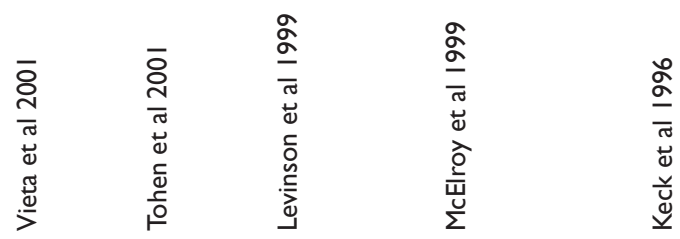

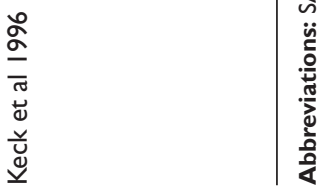


condition producing neurobehavioral disturbances that are potential modifiers of their expression, persistence, and/or treatment-response. While bearing these modifiers in mind, the study, evaluation, and treatment of persons with neurobehavioral disturbances is then organized according to the dimension(s) of neurobehavioral function in which such disturbances are expressed.

It is our assertion that this approach is particularly well-applied to the study, evaluation, and treatment of schizoaffective disorder. This condition reflects aberrations in the distributed neural networks serving both information processing (ie, perception, information interpretation) and emotional regulation, among other possible dimensions of disordered neurobehavioral function, in persons whose presentations are currently described as 'schizoaffective'. It is conceivable that other factors, including genetic and epigenetic variations and environmental contributors, may influence the expression of disturbances in information processing and emotional regulation domains, and that such factors may weigh particularly heavily on one rather than the other. In such circumstances, the presentation would be one that appears to be predominated by either psychotic or mood disturbances rather than by both. Directing the study, evaluation, and treatment at the core disturbances in information processing and/or emotional regulation, regardless of how these disturbances direct assignment of categorical psychiatric disorder, it is likely that a more coherent description of the relevant neurobiology and effective treatments would emerge. By extension, application of this neuropsychiatric approach to other psychiatric disorders may facilitate their study, evaluation, and treatment and also avoid the vagaries entailed by a psychiatric nosology predicated on categorical, and ultimately arbitrary, diagnoses.

\section{Disclosure}

Dr Rojas receives support from MH60214.

\section{References}

Adler CM, Strakowski SM. 2003. Boundaries of schizophrenia. Psychiatr Clin North Am, 26:1-23.

American Psychiatric Association, American Psychiatric Association, and Work Group to Revise DSM-III 1987, Diagnostic and statistical manual of mental disorders DSM-III-R, 3rd ed., rev edn, American Psychiatric Association, Washington, DC.

Angst J, Felder W, Lohmeyer B. 1980. Course of schizoaffective psychoses: results of a follow-up study. Schizophr Bull, 6:579-85.

Angst J, Preisig M. 1995. Course of a clinical cohort of unipolar, bipolar and schizoaffective patients. Results of a prospective study from 1959 to 1985. Schweiz Arch Neurol Psychiatr, 146:5-16.

Arciniegas DB, Kaufer DI. 2006. Core curriculum for training in behavioral neurology and neuropsychiatry. J Neuropsychiatry Clin Neurosci, 18:6-13.
Ardekani BA, Nierenberg J, Hoptman MJ, et al. 2003. MRI study of white matter diffusion anisotropy in schizophrenia. Neuroreport, 14:2025-9.

Baethge C, Gruschka P, Berghofer A, et al. 2004. Prophylaxis of schizoaffective disorder with lithium or carbamazepine: outcome after long-term follow-up. J Affect Disord, 79(1-3):43-50.

Benabarre A, Vieta E, Colom F, et al. 2001. Bipolar disorder, schizoaffective disorder and schizophrenia: epidemiologic, clinical and prognostic differences. Eur Psychiatry, 16:167-72.

Benson KL, Sullivan EV, Lim KO, et al. 1996. Slow wave sleep and computed tomographic measures of brain morphology in schizophrenia. Psychiatry Res, 60(2-3):125-34.

Benson KL, Zarcone VP, Jr. 1982. Middle ear muscle activity during REM sleep in schizophrenic, schizoaffective and depressed patients. Am J Psychiatry, 139:1474-6.

Berner P, Simhandl C. 1983. Approaches to an exact definition of schizoaffective psychoses for research purposes. Psychiatr Clin (Basel), 16(2-4):245-53.

Bilder RM, Goldman RS, Volavka J, et al. 2002. Neurocognitive effects of clozapine, olanzapine, risperidone, and haloperidol in patients with chronic schizophrenia or schizoaffective disorder. Am J Psychiatry, 159:1018-28.

Bilder RM, Wu H, Bogerts B, et al. 1999. Cerebral volume asymmetries in schizophrenia and mood disorders: a quantitative magnetic resonance imaging study. Int J Psychophysiol, 34:197-205.

Borenstein S, Cheron G, Toscano-Aguilar M, et al. 1988. [Comparative study of the amplitude, surface and duration of the pre- and postimperative waves of the CNV (contingent negative variation) in a group of 40 schizophrenic and schizo-affective patients as compared with normal subjects]. Neurophysiol Clin, 18:129-40.

Boutros N, Nasrallah H, Leighty R, et al. 1997. Auditory evoked potentials, clinical vs. research applications. Psychiatry Res, 69(2-3):183-95.

Brenner CA, Sporns O, Lysaker PH, et al. 2003. EEG synchronization to modulated auditory tones in schizophrenia, schizoaffective disorder, and schizotypal personality disorder. Am J Psychiatry, 160:2238-40.

Bruder G, Kayser J, Tenke C, et al. 1998. The time course of visuospatial processing deficits in schizophrenia: an event-related brain potential study. J Abnorm Psychol, 107:399-411.

Bryson G, Bell M, Lysaker P. 1997. Affect recognition in schizophrenia: a function of global impairment or a specific cognitive deficit. Psychiatry Res, 71:105-13.

Bryson G, Greig T, Lysaker P, et al. 2002. Longitudinal Wisconsin card sorting performance in schizophrenia patients in rehabilitation. Appl Neuropsychol, 9:203-9.

Buchanan RW, Francis A, Arango C, et al. 2004. Morphometric assessment of the heteromodal association cortex in schizophrenia. Am J Psychiatry, 161:322-31.

Byerly M, Goodman W, Acholonu W, et al. 2005. Obsessive compulsive symptoms in schizophrenia: frequency and clinical features. Schizophr Res, 76(2-3):309-16.

Cannon TD, Van Erp TG, Huttunen M, et al. 1998. Regional gray matter, white matter, and cerebrospinal fluid distributions in schizophrenic patients, their siblings, and controls. Arch Gen Psychiatry, 55:1084-91.

Cannon TD, Van Erp TG, Rosso IM, et al. 2002. Fetal hypoxia and structural brain abnormalities in schizophrenic patients, their siblings, and controls. Arch Gen Psychiatry, 59:35-41.

Cardno AG, Holmans PA, Rees MI, et al. 2001. A genomewide linkage study of age at onset in schizophrenia. Am J Med Genet, 105:439-45.

Chengappa KN, Parepally H, Brar JS, et al. 2003. A random-assignment, double-blind, clinical trial of once- vs twice-daily administration of quetiapine fumarate in patients with schizophrenia or schizoaffective disorder: a pilot study. Can J Psychiatry, 48:187-94.

Cohen LS. 2003. Gender-specific considerations in the treatment of mood disorders in women across the life cycle. J Clin Psychiatry, 64(Suppl 15):18-29. 
Davis JM, Chen N. 2004. Dose response and dose equivalence of antipsychotics. J Clin Psychopharmacol, 24:192-208.

del Rio Vega JM, Ayuso-Gutierrez JL. 1990. Course of schizoaffective psychosis: a retrospective study. Acta Psychiatr Scand, 81:534-7.

del Rio Vega JM, Ayuso-Gutierrez JL. 1992. Course of schizoaffective psychosis: further data from a retrospective study. Acta PsychiatrScand, 85:328-30.

DeLisi LE, Mesen A, Rodriguez C, et al. 2002. Genome-wide scan for linkage to schizophrenia in a Spanish-origin cohort from Costa Rica. Am J Med Genet, 114:497-508.

Dell'Osso L, Akiskal HS, Freer P, et al. 1993. Psychotic and nonpsychotic bipolar mixed states: comparisons with manic and schizoaffective disorders. Eur Arch Psychiatry Clin Neurosci, 243:75-81.

Dick DM, Foroud T, Flury L, et al. 2003. Genomewide linkage analyses of bipolar disorder: a new sample of 250 pedigrees from the National Institute of Mental Health Genetics Initiative. Am J Hum Genet, 73:107-14

Faraone SV, Skol AD, Tsuang DW, et al. 2002. Linkage of chromosome $13 \mathrm{q} 32$ to schizophrenia in a large veterans affairs cooperative study sample. Am J Med Genet, 114:598-604.

Faustman WO, Bardgett M, Faull KF, et al. 1999. Cerebrospinal fluid glutamate inversely correlates with positive symptom severity in unmedicated male schizophrenic/schizoaffective patients. Biol Psychiatry, 45:68-75.

Frances A, First MB, Pincus HA. 1995, DSM-IV guidebook, 1st ed. Washington, DC: American Pyschiatric Press.

Friedlander RI, Donnelly T. 2004. Early-onset psychosis in youth with intellectual disability. J Intellect Disabil Res, 48(Pt 6):540-7.

Getz GE, DelBello MP, Fleck DE, et al. 2002. Neuroanatomic characterization of schizoaffective disorder using MRI: a pilot study. Schizophr Res, 55(1-2):55-9.

Giouzeli M, Williams NA, Lonie LJ, et al. 2004. ProtocadherinX/Y, a candidate gene-pair for schizophrenia and schizoaffective disorder: a DHPLC investigation of genomic sequence. Am J Med Genet B Neuropsychiatr Genet, 129B:1-9.

Glahn DC, Bearden CE, Cakir S, et al. 2006. Differential working memory impairment in bipolar disorder and schizophrenia: effects of lifetime history of psychosis. Bipolar Disord, 8:117-23.

Goldstein G, Shemansky WJ, Allen DN. 2005. Cognitive function in schizoaffective disorder and clinical subtypes of schizophrenia. Arch Clin Neuropsychol, 20:153-9.

Goode DJ, Manning AA. 1985. Variations in the Hoffmann reflex recovery curve related to clinical manifestations of schizoaffective disorder Psychiatry Res, 15:63-70.

Gooding DC, Tallent KA. 2002. Spatial working memory performance in patients with schizoaffective psychosis versus schizophrenia: a tale of two disorders? Schizophr Res, 53:209-18.

Hamshere ML, Bennett P, Williams N, et al. 2005. Genomewide linkage scan in schizoaffective disorder: significant evidence for linkage at 1q42 close to DISC1, and suggestive evidence at 22q11 and 19p13. Arch Gen Psychiatry, 62:1081-8.

Harrow M, Grossman LS, Herbener ES, et al. 2000. Ten-year outcome: patients with schizoaffective disorders, schizophrenia, affective disorders and mood-incongruent psychotic symptoms. $\mathrm{Br} J$ Psychiatry, 177:421-6.

Harvey PD, Napolitano JA, Mao L, et al. 2003. Comparative effects of risperidone and olanzapine on cognition in elderly patients with schizophrenia or schizoaffective disorder. Int J Geriatr Psychiatry, 18:820-9.

Harvey PD, Siu CO, Romano S. 2004. Randomized, controlled, double-blind, multicenter comparison of the cognitive effects of ziprasidone versus olanzapine in acutely ill inpatients with schizophrenia or schizoaffective disorder. Psychopharmacology (Berl), 172:324-32.

Hodgkinson CA, Goldman D, Jaeger J, et al. 2004. Disrupted in schizophrenia 1 (DISC1): association with schizophrenia, schizoaffective disorder, and bipolar disorder. Am J Hum Genet, 75:862-72.
Hollis C. 2000. Adult outcomes of child- and adolescent-onset schizophrenia: diagnostic stability and predictive validity. Am J Psychiatry, 157:1652-9.

Inui K, Motomura E, Okushima R, et al. 1998. Electroencephalographic findings in patients with DSM-IV mood disorder, schizophrenia, and other psychotic disorders. Biol Psychiatry, 43:69-75.

Ishizuka K, Paek M, Kamiya A, et al. 2006. A review of Disrupted-InSchizophrenia-1 (DISC1): neurodevelopment, cognition, and mental conditions. Biol Psychiatry, 59:1189-97.

Jurjus GJ, Nasrallah HA, Olson SC, et al. 1993. Cavum septum pellucidum in schizophrenia, affective disorder and healthy controls: a magnetic resonance imaging study. Psychol Med, 23:319-22.

Kasanin J. 1994. The acute schizoaffective psychoses. 1933. Am J Psychiatry, 151(6 Suppl):144-54.

Kathmann N, Hochrein A, Uwer R, et al. 2003. Deficits in gain of smooth pursuit eye movements in schizophrenia and affective disorder patients and their unaffected relatives. Am J Psychiatry, 160:696-702.

Kayser J, Bruder GE, Friedman D, et al. 1999. Brain event-related potentials (ERPs) in schizophrenia during a word recognition memory task. Int $J$ Psychophysiol, 34:249-65.

Kayser J, Bruder GE, Tenke CE, et al. 2001. Event-related brain potentials (ERPs) in schizophrenia for tonal and phonetic oddball tasks. Biol Psychiatry, 49:832-47.

Keck PE Jr, McElroy SL, Strakowski SM. 1996. New developments in the pharmacologic treatment of schizoaffective disorder. J Clin Psychiatry, 57(Suppl 9):41-8.

Keshavan MS, Stanley JA, Montrose DM, et al. 2003. Prefrontal membrane phospholipid metabolism of child and adolescent offspring at risk for schizophrenia or schizoaffective disorder: an in vivo 31P MRS study. Mol Psychiatry, 8:316-23, 251.

Keshaven MS, Reynolds CF III, Miewald J, et al. 1995. Slow-wave sleep deficits and outcome in schizophrenia and schizoaffective disorder. Acta Psychiatr Scand, 91:289-92.

Kirov G, Ivanov D, Williams NM, et al. 2004. Strong evidence for association between the dystrobrevin binding protein 1 gene (DTNBP1) and schizophrenia in 488 parent-offspring trios from Bulgaria. Biol Psychiatry, 55:971-5.

Kolakowska T, Williams AO, Jambor K, et al. 1985. Schizophrenia with good and poor outcome. III: Neurological 'soft' signs, cognitive impairment and their clinical significance. Br J Psychiatry, 146:348-57.

Kumar N, Debruille JB. 2004. Semantics and N400: insights for schizophrenia. J Psychiatry Neurosci, 29:89-98.

Kumar R, Marks M, Wieck A, et al. 1993. Neuroendocrine and psychosocial mechanisms in post-partum psychosis. Prog Neuropsychopharmacol Biol Psychiatry, 17:571-9.

Laruelle M, bi-Dargham A, Casanova MF, et al. 1993. Selective abnormalities of prefrontal serotonergic receptors in schizophrenia. A postmortem study. Arch Gen Psychiatry, 50:810-8.

Lenz G, Simhandl C, Thau K, et al. 1991. Temporal stability of diagnostic criteria for functional psychoses. Results from the Vienna follow-up study. Psychopathology, 24:328-35.

Levinson DF, Umapathy C, Musthaq M. 1999. Treatment of schizoaffective disorder and schizophrenia with mood symptoms. Am J Psychiatry, 156:1138-48.

Liddle PF, Laurens KR, Kiehl KA, et al. 2006. Abnormal function of the brain system supporting motivated attention in medicated patients with schizophrenia: an fMRI study. Psychol Med, 36:1097-108.

Lieberman JA, Jody D, Geisler S, et al. 1993a. Time course and biologic correlates of treatment response in first-episode schizophrenia. Arch Gen Psychiatry, 50:369-76.

Lieberman JA, Jody D, Alvir JM, et al. 1993b. Brain morphology, dopamine, and eye-tracking abnormalities in first-episode schizophrenia. Prevalence and clinical correlates. Arch Gen Psychiatry, 50:357-68.

Liu CM, Hwu HG, Fann CS, et al. 2005. Linkage evidence of schizophrenia to loci near neuregulin 1 gene on chromosome 8 p21 in Taiwanese families. Am J Med Genet B Neuropsychiatr Genet, 134:79-83.

Maier W. 2006. Do schizoaffective disorders exist at all? Acta Psychiatr Scand, 113:369-71. 
Maj M, Pirozzi R, Formicola AM, et al. 2000. Reliability and validity of the DSM-IV diagnostic category of schizoaffective disorder: preliminary data. J Affect Disord, 57(1-3):95-8.

Malla AK, Norman RM, Scholten D. 2000. Predictors of service use and social conditions in patients with psychotic disorders. Can J Psychiatry, 45:269-73.

Manschreck TC, Maher BA, Beaudette SM, et al. 1997. Context memory in schizoaffective and schizophrenic disorders. Schizophr Res, 26(2-3):153-61.

Marder SR, McQuade RD, Stock E, et al. 2003. Aripiprazole in the treatment of schizophrenia: safety and tolerability in short-term, placebocontrolled trials. Schizophr Res, 61(2-3):123-36.

Marneros A. 2003. The schizoaffective phenomenon: the state of the art. Acta Psychiatr Scand Suppl, 418:29-33.

Marneros A, Deister A, Rohde A. 1989a. Quality of affective symptomatology and its importance for the definition of schizoaffective disorders. Psychopathology, 22(2-3):152-60.

Marneros A, Deister A, Rohde A. 1990. Psychopathological and social status of patients with affective, schizophrenic and schizoaffective disorders after long-term course. Acta Psychiatr Scand, 82:352-8.

Marneros A, Deister A, Rohde A. 1991. Stability of diagnoses in affective, schizoaffective and schizophrenic disorders. Cross-sectional versus longitudinal diagnosis. Eur Arch Psychiatry Clin Neurosci, 241:187-92.

Marneros A, Deister A, Rohde A, et al. 1989b. Long-term outcome of schizoaffective and schizophrenic disorders: a comparative study. I. Definitions, methods, psychopathological and social outcome. Eur Arch Psychiatry Neurol Sci, 238:118-25.

McClellan J, McCurry C. 1999. Early onset psychotic disorders: diagnostic stability and clinical characteristics. Eur Child Adolesc Psychiatry, 8(Suppl 1):13-9.

McElroy SL, Keck PE Jr, Strakowski SM. 1999. An overview of the treatment of schizoaffective disorder. J Clin Psychiatry, 60(Suppl 5):16-21.

Meltzer HY, Arora RC, Metz J. 1984. Biological studies of schizoaffective disorders. Schizophr Bull, 10:49-70.

Mitrushina M, Abara J, Blumenfeld A. 1996. A comparison of cognitive profiles in schizophrenia and other psychiatric disorders. $J$ Clin Psychol, 52:177-90.

Mokrani M, Duval F, Diep TS, et al. 2000. Multihormonal responses to clonidine in patients with affective and psychotic symptoms. Psychoneuroendocrinology, 25:741-52.

Nangle JM, Clarke S, Morris DW, et al. 2006. Neurocognition and suicidal behaviour in an Irish population with major psychotic disorders. Schizophr Res, 85(1-3):196-200.

Olincy A, Martin L. 2005. Diminished suppression of the P50 auditory evoked potential in bipolar disorder subjects with a history of psychosis. Am J Psychiatry, 162:43-9.

Oltmanns TF, Murphy R, Berenbaum H, et al. 1985. Rating verbal communication impairment in schizophrenia and affective disorders. Schizophr Bull, 11:292-9.

Pini S, de Queiroz V, Dell'Osso L, et al. 2004. Cross-sectional similarities and differences between schizophrenia, schizoaffective disorder and mania or mixed mania with mood-incongruent psychotic features. Eur Psychiatry, 19:8-14.

Pope JW, Kern RS. 2006. An "errorful" learning deficit in schizophrenia? J Clin Exp Neuropsychol, 28:101-10.

Porteous DJ, Thomson P, Brandon NJ, et al. 2006. The genetics and biology of DISC1 - an emerging role in psychosis and cognition. Biol Psychiatry, 60:123-31.

Prasad KM, Rohm BR, Keshavan MS. 2004. Parahippocampal gyrus in first episode psychotic disorders: a structural magnetic resonance imaging study. Prog Neuropsychopharmacol Biol Psychiatry, 28:651-8.

Reite M, Teale P, Rojas DC, et al. 1999. Schizoaffective disorder: evidence for reversed cerebral asymmetry. Biol Psychiatry, 46:133-6.

Roofeh D, Cottone J, Burdick KE, et al. 2006. Deficits in memory strategy use are related to verbal memory impairments in adolescents with schizophrenia-spectrum disorders. Schizophr Res, 85(1-3):201-12.
Saccuzzo DP, Braff DL. 1986. Information-processing abnormalities: trait- and state-dependent components. Schizophr Bull, 12:447-59.

Sajatovic M, Mullen JA, Sweitzer DE. 2002. Efficacy of quetiapine and risperidone against depressive symptoms in outpatients with psychosis. $J$ Clin Psychiatry, 63:1156-63.

Schwartz JE, Fennig S, Tanenberg-Karant M, et al. 2000. Congruence of diagnoses 2 years after a first-admission diagnosis of psychosis. Arch Gen Psychiatry, 57:593-600.

Scully PJ, Owens JM, Kinsella A, et al. 2004. Schizophrenia, schizoaffective and bipolar disorder within an epidemiologically complete, homogeneous population in rural Ireland: small area variation in rate. Schizophr Res, 67(2-3):143-55.

Segurado R, tera-Wadleigh SD, Levinson DF, et al. 2003. Genome scan meta-analysis of schizophrenia and bipolar disorder, part III: Bipolar disorder. Am J Hum Genet, 73:49-62.

Sharma RP, Bissette G, Janicak P, et al. 1994. Cerebrospinal fluid somatostatin concentrations in schizophrenia and schizoaffective disorder: the effects of antipsychotic treatment. Schizophr Res, 13:173-7.

Sharma RP, Faull K, Javaid JI, et al. 1995. Cerebrospinal fluid levels of phenylacetic acid in mental illness: behavioral associations and response to neuroleptic treatment. Acta Psychiatr Scand, 91:293-8.

Sharma RP, Janicak PG, Bissette G, et al. 1997. CSF neurotensin concentrations and antipsychotic treatment in schizophrenia and schizoaffective disorder. Am J Psychiatry, 154:1019-21.

Sharma RP, Javaid JI, Davis JM, et al. 1998. Pretreatment plasma homovanillic acid in schizophrenia and schizoaffective disorder: the influence of demographic variables and the inpatient drug-free period. Biol Psychiatry, 44:488-92.

Sharma RP, Javaid JI, Janicak PG, et al. 1993. Homovanillic acid in the cerebrospinal fluid: patterns of response after four weeks of neuroleptic treatment. Biol Psychiatry, 34:128-34.

Shenton ME, Solovay MR, Holzman P. 1987. Comparative studies of thought disorders. II. Schizoaffective disorder. Arch Gen Psychiatry, 44:21-30.

Skol AD, Young KA, Tsuang DW, et al. 2003. Modest evidence for linkage and possible confirmation of association between NOTCH4 and schizophrenia in a large Veterans Affairs Cooperative Study sample. Am J Med Genet B Neuropsychiatr Genet, 118:8-15.

Spitzer RL, Endicott J, Robins E. 1978. Research diagnostic criteria: rationale and reliability. Arch Gen Psychiatry, 35:773-82.

Staddon S, Arranz MJ, Mancama D, et al. 2005. Association between dopamine D3 receptor gene polymorphisms and schizophrenia in an isolate population. Schizophr Res, 73:49-54

Stip E, Sepehry AA, Prouteau A, et al. 2005. Cognitive discernible factors between schizophrenia and schizoaffective disorder. Brain Cogn, 59:292-5.

Stone WS, Thermenos HW, Tarbox SI, et al. 2005. Medial temporal and prefrontal lobe activation during verbal encoding following glucose ingestion in schizophrenia: A pilot fMRI study. Neurobiol Learn Mem, 83:54-64.

Strakowski SM, Keck PE Jr, Arnold LM, et al. 2003. Ethnicity and diagnosis in patients with affective disorders. $J$ Clin Psychiatry, 64:747-54.

Strauss JL, Calhoun PS, Marx CE, et al. 2006. Comorbid posttraumatic stress disorder is associated with suicidality in male veterans with schizophrenia or schizoaffective disorder. Schizophr Res, 84:165-9.

Szeszko PR, Ardekani BA, Ashtari M, et al. 2005. White matter abnormalities in first-episode schizophrenia or schizoaffective disorder: a diffusion tensor imaging study. Am J Psychiatry, 162:602-5.

Teale P, Reite M, Rojas DC, et al. 2000. Fine structure of the auditory M100 in schizophrenia and schizoaffective disorder. Biol Psychiatry, 48:1109-12.

Tohen M, Strakowski SM, Zarate C Jr, et al. 2000. The McLean-Harvard first-episode project: 6-month symptomatic and functional outcome in affective and nonaffective psychosis. Biol Psychiatry, 48:467-76.

Tohen M, Zhang F, Keck PE, et al. 2001. Olanzapine versus haloperidol in schizoaffective disorder, bipolar type. $J$ Affect Disord, 67(1-3):133-40. 
Tsuang D, Coryell W. 1993. An 8-year follow-up of patients with DSM-III-R psychotic depression, schizoaffective disorder, and schizophrenia. Am J Psychiatry, 150:1182-8.

Ujike H, Takehisa Y, Takaki M, et al. 2001. NOTCH4 gene polymorphism and susceptibility to schizophrenia and schizoaffective disorder. Neurosci Lett, 301:41-4.

Van Erp TG, Saleh PA, Huttunen M, et al. 2004. Hippocampal volumes in schizophrenic twins. Arch Gen Psychiatry, 61:346-53.

Vieta E, Herraiz M, Fernandez A, et al. 2001. Efficacy and safety of risperidone in the treatment of schizoaffective disorder: initial results from a large, multicenter surveillance study. Group for the Study of Risperidone in Affective Disorders (GSRAD). J Clin Psychiatry, 62:623-30.

Vollmer-Larsen A, Jacobsen TB, Hemmingsen R, et al. 2006. Schizoaffective disorder - the reliability of its clinical diagnostic use. Acta Psychiatr Scand, 113:402-7.

Weiss J, Magert HJ, Cieslak A, et al. 1996. Association between different psychotic disorders and the DRD4 polymorphism, but no differences in the main ligand binding region of the DRD4 receptor protein compared to controls. Eur J Med Res, 1:439-45.

Werry JS, McClellan JM, Chard L. 1991. Childhood and adolescent schizophrenic, bipolar, and schizoaffective disorders: a clinical and outcome study. J Am Acad Child Adolesc Psychiatry, 30:457-65.
Whaley AL. 2002. Symptom clusters in the diagnosis of affective disorder, schizoaffective disorder, and schizophrenia in African Americans. J Natl Med Assoc, 94:313-9.

Wijsman EM, Rosenthal EA, Hall D, et al. 2003. Genome-wide scan in a large complex pedigree with predominantly male schizophrenics from the island of Kosrae: evidence for linkage to chromosome 2q. Mol Psychiatry, 8:695-705, 643.

Willour VL, Zandi PP, Huo Y, et al. 2003. Genome scan of the fifty-six bipolar pedigrees from the NIMH genetics initiative replication sample: chromosomes 4, 7, 9, 18, 19, 20, and 21. Am J Med Genet B Neuropsychiatr Genet, 121:21-7.

Wilson M. 1993. DSM-III and the transformation of American psychiatry: a history. Am J Psychiatry, 150:399-410.

Winokur G, Monahan P, Coryell W, et al. 1996. Schizophrenia and affective disorder - distinct entities or continuum? An analysis based on a prospective 6-year follow-up. Compr Psychiatry, 37:77-87.

Woodward TS, Thornton AE, Ruff CC, et al. 2004. Material-specific episodic memory associates of the psychomotor poverty syndrome in schizophrenia. Cognit Neuropsychiatry, 9:213-27.

Zarate CA Jr, Tohen M, Baraibar G, et al. 1997. Shifts in hospital diagnostic frequencies: bipolar disorder subtypes, 1981-1993. J Affect Disord, 43:79-84. 
